\title{
Trends in China's anthropogenic emissions since 2010 as the consequence of clean air actions
}

\author{
Bo Zheng ${ }^{1, \text { a }}$, Dan Tong ${ }^{2}$, Meng Li ${ }^{2}$, Fei Liu ${ }^{1}$, Chaopeng Hong ${ }^{2}$, Guannan Geng ${ }^{2}$, Haiyan $\mathrm{Li}^{1}, \mathrm{Xin} \mathrm{Li}^{2}$, Liqun Peng ${ }^{1}$, \\ Ji Qi $^{1}$, Liu Yan ${ }^{2}$, Yuxuan Zhang ${ }^{2}$, Hongyan Zhao ${ }^{2}$, Yixuan Zheng ${ }^{2}$, Kebin $\mathrm{He}^{1,2}$, and Qiang Zhang ${ }^{2}$ \\ ${ }^{1}$ State Key Joint Laboratory of Environment Simulation and Pollution Control, School of Environment, Tsinghua University, \\ Beijing 100084, People's Republic of China \\ ${ }^{2}$ Ministry of Education Key Laboratory for Earth System Modeling, Department of Earth System Science, \\ Tsinghua University, Beijing, China \\ apresent address: Laboratoire des Sciences du Climat et de l'Environnement, CEA-CNRS-UVSQ, \\ UMR8212, Gif-sur-Yvette, France
}

Correspondence: Qiang Zhang (qiangzhang@tsinghua.edu.cn)

Received: 10 April 2018 - Discussion started: 2 May 2018

Revised: 26 August 2018 - Accepted: 11 September 2018 - Published: 4 October 2018

\begin{abstract}
To tackle the problem of severe air pollution, China has implemented active clean air policies in recent years. As a consequence, the emissions of major air pollutants have decreased and the air quality has substantially improved. Here, we quantified China's anthropogenic emission trends from 2010 to 2017 and identified the major driving forces of these trends by using a combination of bottom-up emission inventory and index decomposition analysis (IDA) approaches. The relative change rates of China's anthropogenic emissions during 2010-2017 are estimated as follows: $-62 \%$ for $\mathrm{SO}_{2},-17 \%$ for $\mathrm{NO}_{x},+11 \%$ for nonmethane volatile organic compounds (NMVOCs), $+1 \%$ for $\mathrm{NH}_{3},-27 \%$ for $\mathrm{CO},-38 \%$ for $\mathrm{PM}_{10},-35 \%$ for $\mathrm{PM}_{2.5}$, $-27 \%$ for $\mathrm{BC},-35 \%$ for $\mathrm{OC}$, and $+16 \%$ for $\mathrm{CO}_{2}$. The IDA results suggest that emission control measures are the main drivers of this reduction, in which the pollution controls on power plants and industries are the most effective mitigation measures. The emission reduction rates markedly accelerated after the year 2013, confirming the effectiveness of China's Clean Air Action that was implemented since 2013. We estimated that during 2013-2017, China's anthropogenic emissions decreased by $59 \%$ for $\mathrm{SO}_{2}, 21 \%$ for $\mathrm{NO}_{x}, 23 \%$ for $\mathrm{CO}, 36 \%$ for $\mathrm{PM}_{10}, 33 \%$ for $\mathrm{PM}_{2.5}, 28 \%$ for $\mathrm{BC}$, and $32 \%$ for OC. NMVOC emissions increased and $\mathrm{NH}_{3}$ emissions remained stable during 2010-2017, representing the absence of effective mitigation measures for NMVOCs and $\mathrm{NH}_{3}$ in current policies. The relative contributions of differ-
\end{abstract}

ent sectors to emissions have significantly changed after several years' implementation of clean air policies, indicating that it is paramount to introduce new policies to enable further emission reductions in the future.

\section{Introduction}

China produces the most air pollution in the world and contributes $18-35 \%$ of global air pollutant emissions (Hoesly et al., 2018). The major air pollutants China emits the most include sulfur dioxide $\left(\mathrm{SO}_{2}\right)$, nitrogen oxides $\left(\mathrm{NO}_{x}\right)$, carbon monoxide (CO), nonmethane volatile organic compounds (NMVOCs), ammonia $\left(\mathrm{NH}_{3}\right)$, and particulate matter (PM), including black carbon (BC) and organic carbon (OC). These pollutants constitute the majority of the precursors of $\mathrm{PM}_{2.5}$ and $\mathrm{O}_{3}$ pollution as well as those of short-lived climate forcers, which exert harmful effects on human health, agriculture, and regional climate. These pollutants not only cause local to regional environmental problems such as premature deaths and agricultural yield losses but also have a significant impact on regional climate changes in temperature and precipitation. To tackle the problems of both air pollution and regional climate change, it is important to fully understand the trends and drivers of Chinese emissions.

The years since 2010 have been an extraordinary period for China in the fight against air pollution. For the first time, 
China has added the index of $\mathrm{PM}_{2.5}$ into its air quality standards, with an annual upper mean limit of $35 \mu \mathrm{g} \mathrm{m}^{-3}$ (Zhang et al., 2012). In 2013, the annual average concentrations of $\mathrm{PM}_{2.5}$ were 106,67 , and $47 \mu \mathrm{g} \mathrm{m}^{-3}$ in Beijing-TianjinHebei, the Yangtze River Delta, and the Pearl River Delta, respectively; these concentrations are all worse than China's $35 \mu \mathrm{g} \mathrm{m}^{-3}$ standard and 5 to 10 times higher than the WHO's $\mathrm{PM}_{2.5}$ guideline value of $10 \mu \mathrm{g} \mathrm{m}^{-3}$ (World Health Organization, 2006). To attain this air quality standard, China has strengthened its emission standards to achieve reductions in air pollutant emissions. These upgraded emission standards and the timeline for their implementation have accelerated since 2013 when the Action Plan on the Prevention and Control of Air Pollution (denoted as the Clean Air Action) was implemented (China State Council, 2013). The Clean Air Action is China's first 5-year plan (2013-2017) that radically tightened air pollution targets for particulate matter pollution reduction. The three metropolitan regions mentioned above were required to reduce $\mathrm{PM}_{2.5}$ concentrations by $15-25 \%$ by the year 2017 compared with the 2013 levels, and all other provinces in China were required to reduce $\mathrm{PM}_{10}$ concentrations by $10 \%$. The Clean Air Action launched stringent measures to achieve these air quality targets, including the adjustment of energy mix and industrial structure, the reduction of air pollutant emissions, the establishment of monitoring and early-warning systems for air pollution, and other supportive policies. With the successful policy implementation, China met the 2017 air pollution target set under 2013 Clean Air Action, and the annual average $\mathrm{PM}_{2.5}$ concentrations reduced by $28-40 \%$ from 2013 to 2017 in the three metropolitan regions (China, 2018). Space- and ground-based observations have also confirmed the improvement of China's air quality (Krotkov et al., 2016; Liu et al., 2016; Zhang et al., 2017; Zhao et al., 2017; Zheng et al., 2018).

Establishing linkages between air quality improvements and mitigation efforts requires the use of the most recent emission inventory. However, there are no official data about how much air pollutants are emitted by China every year. The inventories developed by researchers often lag several years behind the present, leaving China without up-todate emission inventories. Currently, there are no emission datasets that cover the period of 2010-2017. To understand the progress in air cleaning, we are in urgent need of China's most recent emission inventories, which will benefit both scientific studies and policy-making. Given that China accounts for approximately one-third of global emissions, these data will also facilitate a better understanding of the latest trends in global emissions.

In this paper, we analyze the key trends and drivers of China's anthropogenic emissions from 2010 to 2017. During this period, China announced unprecedented measures to improve air quality. The purpose of this study is to summarize what China has done in recent years and to evaluate how these actions have influenced anthropogenic emission trends. We first provide a comprehensive overview of
China's clean air actions since 2010, especially the stringent measures that took effect after 2013 (Sect. 2). Then, we use a bottom-up method (Sect. 3) to estimate the 20102017 trend in Chinese emissions (Sect. 4.1) shaped by these mitigation measures. The driving factors are analyzed at the national and sectoral levels using the approach of index decomposition analysis (Sect. 4.2). We separate the influence of pollution control from the influence of economic growth on the emission trend. Finally, the emission trends are evaluated against space- and ground-based observations of $\mathrm{SO}_{2}$, $\mathrm{NO}_{2}$, and $\mathrm{PM}_{2.5}$, as well as top-down constraints inferred from these observations (Sect. 4.3). Concluding remarks are given in Sect. 5.

\section{China's clean air actions}

The clean air policies that have been implemented by China since 2010 are summarized in Fig. 1. These mitigation measures cover all the major source sectors and have become increasingly stringent over time. Before 2013, strengthening the emission standards for power and industrial sectors was the key pollution control measure. For example, the emission limits of coal-fired power plants were $400 \mathrm{mg} \mathrm{m}^{-3}$ for $\mathrm{SO}_{2}, 450-1100 \mathrm{mg} \mathrm{m}^{-3}$ for $\mathrm{NO}_{x}$, and $50 \mathrm{mg} \mathrm{m}^{-3}$ for particulates before 2012 (the standard GB 13223-2003). After 2012, all new and existing coal-fired plants were required to achieve new limit values of $\mathrm{SO}_{2}, \mathrm{NO}_{x}$, and particulates of 100 (200 for existing units), 100 , and $30 \mathrm{mg} \mathrm{m}^{-3}$ (the standard GB 13223-2011), respectively. China also set new emission standards for the flat glass industry and the iron and steel industry before 2013. Because other industries (e.g., the cement industry and industrial boilers) lacked stringent emission standards, they still used outdated legislation on emission limits implemented approximately 10 years ago during the period of 2010-2013.

China committed to reducing $\mathrm{PM}_{2.5}$ pollution in 2013 for the first time ever. To fulfill the air quality target set under 2013 Clean Air Action, the government developed eight pollution control measures that were more stringent and ambitious than ever before. With these new measures, the emission limits set by existing standards were further tightened, and more stringent emission source controls were adopted not only to reduce emissions but also to improve energy efficiency and promote a structural change in energy use patterns. We briefly describe the eight measures implemented during 2013-2017 in the following section.

1. "Ultralow" emission standard for power plants. Strengthening emission standards is key in the pollution control of coal-fired power plants. With the 2012 emission standard enacted and fully met, China pledged in December 2015 to further reduce emissions from coal power by $60 \%$ by 2020 using the ultralow emission technique. The emission limits for $\mathrm{SO}_{2}, \mathrm{NO}_{x}$, and particulates are 35,50 , and $10 \mathrm{mg} \mathrm{m}^{-3}$, respectively, which 


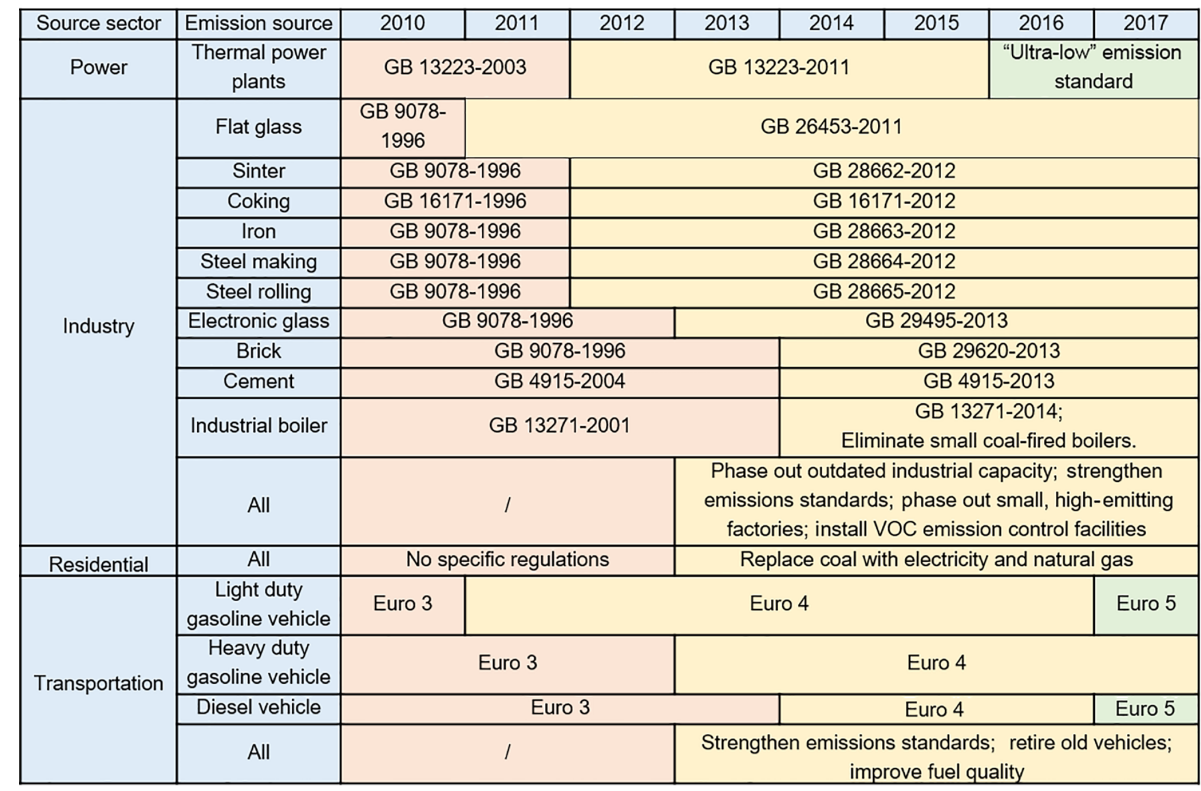

Figure 1. China's clean air policies implemented during 2010-2017.

means that emissions from coal-fired plants must be brought to the level of those from gas-fired plants. Of the current power plants, $71 \%$ operated close to ultralow emission levels in 2017 (China, 2018). This figure is estimated on the basis of firm-level information of pollution control devices and efficiencies, which are collected from each plant by local agencies, and then managed and verified by Ministry of Ecology and Environment in China. The power plants that comply with ultralow emission standards are mainly large ones at the current stage. Most of them use continuous emission monitoring systems to monitor exhaust emissions, which confirm that these plants are indeed complying with the ultralow emission levels.

2. Phase out outdated industrial capacity. Small and inefficient factories that cannot meet efficiency, environment, or safety standards have been eliminated in recent years. As a result, the average energy intensity, or energy consumed per unit of industrial gross output, steadily decreased for steel $(-3.3 \%)$, cement $(-2.9 \%)$, aluminum $(-1.0 \%)$, ethylene $(-4.2 \%)$, and synthetic ammonia (-3.0\%) from 2013 to 2016 (National Bureau of Statistics, 2018a). The average efficiency of coalfired power units, or grams of coal equivalent (gce) consumed per kilowatt-hour of the power supply, improved from 321 to $309 \mathrm{gce} \mathrm{kWh}^{-1}$ from 2013 to 2017 (National Bureau of Statistics, 2018a; National Energy Administration, 2018).

3. Strengthen industrial emission standards. Since 2013, all industrial emission standards have been strengthened; limits have been tightened and the targeted emis- sion sources and air pollutants have been expanded. Figure 1 summarizes all the national emission standards specific to air pollutants, and there are another 22 comprehensive standards that specify the maximum amounts of waste materials in gas and water for different industries. These standards, including both new and upgraded ones from previous levels, have covered all the emission-intensive industries in China, including iron and steel making, cement, brick, coke, glass, and chemical industries. For example, the emission limits of cement plants were $800 \mathrm{mg} \mathrm{m}^{-3}$ for $\mathrm{NO}_{x}$ and $50 \mathrm{mg} \mathrm{m}^{-3}$ for particulates before 2014 (the standard GB 4915-2004), while after 2014 all cement plants were required to reach new limit values of $400 \mathrm{mg} \mathrm{m}^{-3}$ for $\mathrm{NO}_{x}$ and of $30 \mathrm{mg} \mathrm{m}^{-3}$ for particulates (the standard GB 4915-2013). For coal boilers used in industries, the emission limits were $900 \mathrm{mg} \mathrm{m}^{-3}$ for $\mathrm{SO}_{2}$ and $80-250 \mathrm{mg} \mathrm{m}^{-3}$ for particulates before 2014 (the standard GB 13271-2001), and no limits were required for $\mathrm{NO}_{x}$. After 2014, new coal-fired industrial boilers faced stricter limit values of 300,300 , and $50 \mathrm{mg} \mathrm{m}^{-3}$ for $\mathrm{SO}_{2}, \mathrm{NO}_{x}$, and particulates (the standard GB 132712014), respectively. The new emission standard also tightened the limit values for existing coal-fired industrial boilers, where the "not to exceed" limits for $\mathrm{SO}_{2}$, $\mathrm{NO}_{x}$, and particulates were 400,400 , and $80 \mathrm{mg} \mathrm{m}^{-3}$, respectively.

4. Phase out small high-emitting factories. The tightened emission standards have driven industries to upgrade and adopt cleaner technologies. Small and polluting factories that cannot meet emission standards are being 
retired and replaced with larger facilities. Large industrial plants that have the potential to improve their overall performance by upgrading are required to meet the latest emission legislation as early as possible. These plants must operate close to or better than the original design performance and install end-of-pipe pollution control devices to reduce emissions.

5. Install NMVOC emission control facilities. The petrochemical industry has been required to implement the leak detection and repair (LDAR) program and cut NMVOC emissions by $30 \%$ by 2017 . In addition, a wide range of solvent-using activities also increases NMVOC emissions. Solvents appear in many industrial processes, such as dissolving substances, providing media for chemical reactions, and acting as a dispersion medium for coatings. High solids and waterborne paints contain much fewer organic chemicals, and powder coatings and liquid coatings are both solventfree. The substitution of these new solvents and coating techniques represents the latest requirement of China's emission standards.

6. Eliminate small coal-fired industrial boilers. China shut down all coal boilers with capacities of smaller than $7 \mathrm{MW}$ in urban areas by the end of 2017 and cleaned all existing and new large boilers with $\mathrm{SO}_{2}$ and particulate control technologies. The elimination of small coal-fired boilers in suburban and rural areas is still in progress.

7. Replace residential coal use with electricity and natural gas. Direct coal-burning in the residential sector is being replaced with natural gas and electricity to tackle air pollution in the countryside (China, 2018). China is striving to switch to electricity and gas-powered heating from coal in millions of residences in northern China. To facilitate this fuel switch, northern Chinese provinces have cut nonpeak household power prices to reduce the cost of electric heating, and new gas heating systems are being built in suburban and rural regions. These policies can reduce coal use in the residential sector.

8. Strengthen vehicle emissions standards, retire old vehicles, and improve fuel quality. Tightened emission standards have also driven automakers to adopt cleaner technologies. Fuel economy standards have allowed automakers to reduce the amount of fuel use by new cars

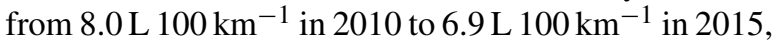
and the 2020 target is $5.0 \mathrm{~L} 100 \mathrm{~km}^{-1}$ (China State Council, 2016). These fuel economy data are based on laboratory tests under the European standard driving cycle, while the real-world fuel consumption rates are typically $15 \%$ higher than these tested values (Huo et al., 2011) because the European test procedure cannot reflect the real urban and highway driving conditions in China. The latest Euro 5 emission standards were implemented in 2017, and newly registered vehicles must comply with these more stringent emission standards. Additionally, all "yellow label" vehicles were eliminated by the end of 2017. "Yellow label" vehicles refer to gasoline and diesel vehicles that fail to meet Euro 1 and Euro 3 standards, respectively.

\section{Methods and data}

\subsection{Bottom-up emission inventory}

Here, we use the framework of the MEIC (Multi-resolution Emission Inventory for China, http://www.meicmodel.org, last access: 30 September 2018) to estimate China's anthropogenic emissions from 2010 to 2017. MEIC is a bottomup emission inventory model which covers 31 provinces in mainland China and includes $\sim 700$ anthropogenic sources. Emissions for each source in each province are estimated as follows:

$$
\begin{aligned}
& \operatorname{Emis}_{i, j, k} \\
& \quad=A_{i, j} \times \sum_{m}\left(X_{i, j, m} \times \mathrm{EF}_{i, j, k, m} \times \sum_{n}\left(C_{i, j, m, n}\right.\right. \\
& \left.\left.\quad \times\left(1-\eta_{k, n}\right)\right)\right),
\end{aligned}
$$

where $i$ represents the province, $j$ represents the emission source, $k$ represents the air pollutants or $\mathrm{CO}_{2}, m$ represents the technologies for manufacturing, $n$ represents the technologies for air pollution control, $A$ is the activity rate, $X$ is the fraction of a specific manufacturing technology, $\mathrm{EF}$ is the unabated emission factor, $C$ is the penetration of a specific pollution control technology, and $\eta$ is the removal efficiency. The details of the technology-based approach and source classifications can be found in Zhang et al. (2007, 2009), Lei et al. (2011), and M. Li et al. (2017a).

The underlying data in the MEIC model are gathered from different sources. Activity rates of energy consumptions by fuel type, by sector, and by province are derived from Chinese Energy Statistics (National Bureau of Statistics, 2018a, b; National Energy Administration, 2018). Productions of various industrial products and penetration of different technologies are collected from a wide variety of statistics (for details, please refer to Lu et al., 2010; Lei et al., 2011). We also use unpublished data from the Ministry of Ecology and Environment to supplement the technology penetration data that are absent in statistics (Qi et al., 2017; Zheng et al., 2017). These data are collected from each plant by local agencies, and then managed and verified by Ministry of Ecology and Environment. The information adopted in this study include pollution control technologies, penetrations, and efficiencies for electric generators, cement facto- 
ries, iron- and steel-making furnaces, and glass kilns in each province, which are used to calibrate emission control levels (i.e., $C$ and $\eta$ in Eq. 1) in the bottom-up inventory. Detailed activity rates by province for the year 2017 are not available when the emission trends presented in this work were developed. In this case, we used national activity data for the year 2017 (National Bureau of Statistics, 2018b; National Energy Administration, 2018) and downscaled these national total data to each province using the weighting factors from 2016 data at the provincial level. Unabated emission factors in MEIC are compiled from a wide range of previous studies, for instance, $\mathrm{SO}_{2}$ from Lu et al. (2010), $\mathrm{NO}_{x}$ from Zhang et al. (2007), NMVOCs from Li et al. (2014), CO from Streets et al. (2006), primary aerosols ( $\mathrm{PM}_{10}, \mathrm{PM}_{2.5}, \mathrm{BC}$, and $\left.\mathrm{OC}\right)$ from Lei et al. (2011), and $\mathrm{CO}_{2}$ from Liu et al. (2015a). We then override those data by local emission factors summarized in M. Li et al. (2017b) wherever available, to represent the most recent progress on emission factor developments in China.

Emissions from power plants are estimated following the unit-based approach developed by Liu et al. (2015b). In summary, we track the emissions of each unit from electricity generation, fuel quality, and the progress in emission control using unit-specific parameters. Emissions from on-road vehicles are estimated using a county-level emission model developed by Zheng et al. (2014), which resolves the spatialtemporal variability of vehicle ownership, fleet turnover (i.e., new technology penetration), and emission factors. Detailed documentation of the method and data for power plants and on-road vehicles can be found in Liu et al. (2015b) and Zheng et al. (2014), respectively.

\subsection{Index decomposition analysis}

We use index decomposition analysis (IDA) to study the driving forces of China's anthropogenic emissions from 2010 to 2017. IDA is one of the major techniques used to analyze the impact of changes in indicators on emission trends (Hoekstra and van den Bergh, 2003). The IDA method is described as follows.

Equation (1) can be converted to a matrix form using the following formula:

$\operatorname{Emis}_{i, j, k}=A_{i, j} \boldsymbol{x} \mathbf{E} \boldsymbol{\eta}$.

The technology distribution factors $X_{i, j, m}$ in Eq. (1) are assembled into the row vector $\boldsymbol{x}$, and the relevant unabated emission factors $\mathrm{EF}_{i, j, k, m}$ are assembled into a diagonal matrix E. The column vector $\boldsymbol{\eta}$ represents the average removal efficiencies weighted by the penetration rates $C_{i, j, m, n}$ of all types of pollution control technologies. According to Eq. (2), over a given period of time, any changes in emissions can be decomposed into their component driving factors using Eq. (3).

$$
\begin{aligned}
& \Delta \mathrm{Emis}_{i, j, k}=\Delta A_{i, j} \boldsymbol{x} \mathbf{E} \boldsymbol{\eta}+A_{i, j} \Delta \boldsymbol{x} \mathbf{E} \boldsymbol{\eta}+A_{i, j} \boldsymbol{x} \Delta \mathbf{E} \boldsymbol{\eta} \\
& \quad+A_{i, j} \boldsymbol{x} \mathbf{E} \Delta \boldsymbol{\eta},
\end{aligned}
$$

where $\Delta$ is the difference operator. The four multiplicative terms in Eq. (2) are converted into four additive terms in Eq. (3). Each additive term represents the contribution of one driving factor to the changes in emissions, while all other factors are kept constant. For example, $\Delta \boldsymbol{\eta}$ is the change in pollutant removal efficiencies and the last term in Eq. (3) represents the change in total emissions caused by end-of-pipe abatement measures, with the activity range $A_{i, j}$, technology distribution $\boldsymbol{x}$, and unabated emission factor $\mathbf{E}$ assumed to be constant.

Technically, the decomposition of four factors in Eq. (3) has $4 !=24$ unique first-order decomposition results. In this study, we use the average of all possible first-order decompositions (Dietzenbacher and Los, 1998) in the analysis of emission drivers. By way of illustration, one of the 24 possible decompositions is shown in Eq. (4).

$$
\begin{aligned}
& \Delta \text { Emis }_{i, j, k} \\
& \quad=\operatorname{Emis}_{i, j, k}\left(t_{1}\right)-\text { Emis }_{i, j, k}\left(t_{0}\right) \\
& \quad=\Delta A_{i, j} \boldsymbol{x}\left(t_{1}\right) \mathbf{E}\left(t_{1}\right) \boldsymbol{\eta}\left(t_{1}\right)+A_{i, j}\left(t_{0}\right) \Delta \boldsymbol{x} \mathbf{E}\left(t_{1}\right) \boldsymbol{\eta}\left(t_{1}\right) \\
& \quad+A_{i, j}\left(t_{0}\right) \boldsymbol{x}\left(t_{0}\right) \Delta \mathbf{E} \boldsymbol{\eta}\left(t_{1}\right)+A_{i, j}\left(t_{0}\right) \boldsymbol{x}\left(t_{0}\right) \mathbf{E}\left(t_{0}\right) \Delta \boldsymbol{\eta} .
\end{aligned}
$$

The decomposition analysis generates a four-dimensional array with dimensions that represent the year (2010-2017), province $($ size $=31)$, emission source $($ size $>700)$, and emission drivers (i.e., $A, \boldsymbol{x}, \mathbf{E}$, and $\boldsymbol{\eta}$ in Eq. 2). This means that for each pollutant, the year-to-year change in emissions can be attributed to the drivers of $A, \boldsymbol{x}, \mathbf{E}$, and $\boldsymbol{\eta}$ by source and by province. $A$ is the activity effect (e.g., fuel combustion), and the other three factors constitute the overall effect of air pollution control. This study is mainly concerned with source contributions rather than province contributions; hence, we sum the 4-D array of the decomposition analysis results along the province dimension and perform the following analysis at the country scale.

\subsection{Satellite-based and in situ observations}

We adopt atmospheric observations to evaluate and validate the emission trends estimated in this study. We use $\mathrm{NO}_{2}$ column retrievals from the DOMINO V2 product (Boersma et al., 2011) and $\mathrm{SO}_{2}$ column retrievals from the Ozone Monitoring Instrument (OMI) V3 product (Krotkov et al., 2015). The 2010-2017 trends of satellite observations are calculated over eastern China, where anthropogenic sources are dominant relative to natural sources and are compared against the emission trends of $\mathrm{NO}_{x}$ and $\mathrm{SO}_{2}$, respectively. Several recent papers have used satellite retrievals to infer recent trends in emissions from East Asia or China. These results are summarized in this study and compared to our emission estimates. We also collect surface-level $\mathrm{SO}_{2}, \mathrm{NO}_{2}$, and $\mathrm{PM}_{2.5}$ 
concentration data from national air quality monitoring stations (http://106.37.208.233:20035/, last access: 30 September 2018) for the period of 2013-2017. These real-time monitoring stations were established in 2013 and had the ability to report hourly concentrations of criteria pollutants from over 1400 sites in 2017.

\section{Results and discussion}

\subsection{Emission trends}

China's anthropogenic emissions are estimated to have declined by $62 \%$ for $\mathrm{SO}_{2}, 17 \%$ for $\mathrm{NO}_{x}, 27 \%$ for $\mathrm{CO}, 38 \%$ for $\mathrm{PM}_{10}, 35 \%$ for $\mathrm{PM}_{2.5}, 27 \%$ for $\mathrm{BC}$, and $35 \%$ for $\mathrm{OC}$ since 2010 (Table 1). Most of these emission reductions have been achieved since 2013 when the Clean Air Action was enacted and implemented. $\mathrm{SO}_{2}$ and $\mathrm{NO}_{x}$ are the only air pollutants that were incorporated into national economic and social development plans with emission reduction targets in China. The 12th 5-Year Plan required the total national emissions of $\mathrm{SO}_{2}$ and $\mathrm{NO}_{x}$ to be cut by $8 \%$ and $10 \%$ from 2011 to 2015, respectively, while the actual reductions were much larger than planned due to the more stringent pollution control requirements implemented after 2013. During this period, our estimates suggest that $\mathrm{CO}$ emissions decreased by $23 \%$, whereas $\mathrm{CO}_{2}$ emissions were flat, reflecting China's improved combustion efficiency and emission control. The years since 2013 also observed a sharp drop in particulate emissions, in contrast with the flattening emissions observed before 2013. This trend is more evident for coarse particles because they are more easily removed by end-of-pipe abatement measures. Given that China's economy is growing rapidly, China's emissions are decoupling from population, economic, and energy consumption growth (Fig. 2). China's gross domestic product grew by $7.6 \%$ per year from 2010 and achieved $67 \%$ growth by 2017; however, China's emissions flattened out from 2010 to 2013, followed by a significant decrease after 2013 according to our calculations. In contrast, NMVOC emissions are estimated to have increased by $11 \%$ and $\mathrm{NH}_{3}$ emissions remained flat from 2010 to 2017 ; these trends were mainly due to the absence of effective emission control measures.

We present the sectoral trends of China's emissions in Figs. 3 and 4. The most important sector identified by our estimates is the industrial sector, which is the dominant source of $\mathrm{SO}_{2}, \mathrm{NO}_{x}, \mathrm{PM}_{10}, \mathrm{PM}_{2.5}$, and $\mathrm{CO}_{2}$ emissions during 2010-2017, accounting for average values of $60 \%, 38 \%$, $57 \%, 50 \%$, and $53 \%$ of total emissions, respectively. The industrial sector is the driver of changes in 2010-2017 emissions for these pollutants, except for $\mathrm{NO}_{x}$ and $\mathrm{CO}_{2}$, and it also drives down $\mathrm{CO}$ and $\mathrm{BC}$ emissions. The power sector, though accounting for more than half of burning coal, is not a dominant contributor to the emissions of any pollutant. The reason for this is that upgrading plants with pollution control

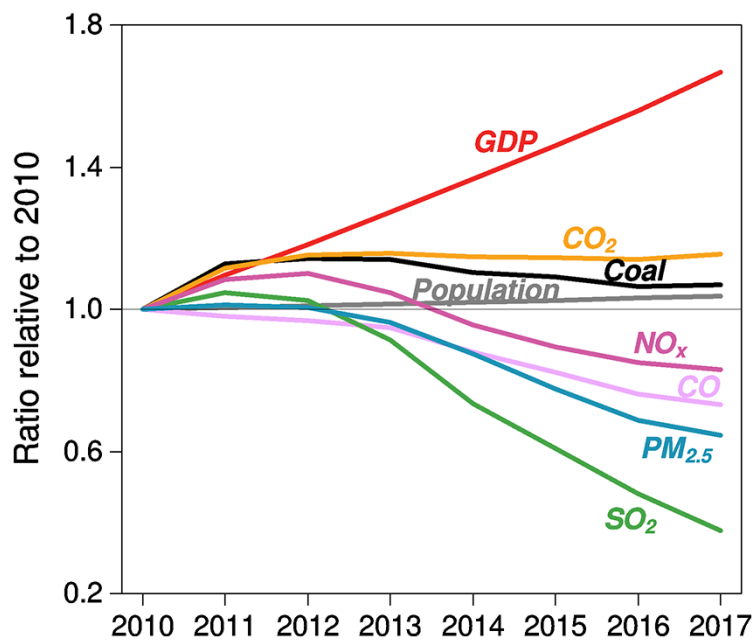

Figure 2. Emission trends and underlying social and economic factors. The coal usage is achieved from Chinese Energy Statistics (National Bureau of Statistics, 2018a, b). The GDP and population data come from the National Bureau of Statistics $(2018 b, c)$. Data are normalized by dividing the value of each year by their corresponding value in 2010 .

equipment in the 11th 5-Year Plan (2006-2010) significantly reduced $\mathrm{SO}_{2}$ and particulate emissions from power plants (Liu et al., 2015b), and the remaining part is not compared to industrial emissions. With upgraded emission standards and the spread of the ultralow emission technique, the new emission limit values have further driven down power plant emissions, which is the dominant driving force of the decrease in $\mathrm{NO}_{x}$ emissions, while industrial combustion sources lack an effective control on $\mathrm{NO}_{x}$.

The residential sector is the dominant source of $\mathrm{CO}, \mathrm{BC}$, and $\mathrm{OC}$, to which it contributes average values of $40 \%$, $49 \%$, and $79 \%$ to national emissions, respectively, and is the second-most important source of $\mathrm{PM}_{10}(31 \%)$ and $\mathrm{PM}_{2.5}$ $(38 \%)$; its relative contributions of these components have increased while industrial emissions have considerably decreased. The residential sector drives OC emissions down and contributes to the reductions of CO, NMVOCs, and particulate matter. The transportation sector accounts for $17 \%$ of CO emissions, $19 \%$ of NMVOC emissions, and $31 \%$ of $\mathrm{NO}_{x}$ emissions. The increase in fuel consumption drives up transport $\mathrm{CO}_{2}$ emissions, with an increase of $43 \%$ from 2010 to 2017 that is faster than that of any other emission source sector. Solvent use is a major contributor to the increase in NMVOC emissions. Solvent emissions are estimated to have increased by $52 \%$ since 2010 , making them the largest contributor (36\%) to NMVOC emissions in 2017, while the share of this sector was only $27 \%$ in 2010 . The agricultural sector is the dominant source of $\mathrm{NH}_{3}$ emissions, as it contributes to $93 \%$ of total emissions. $\mathrm{NH}_{3}$ emissions 
Table 1. Anthropogenic emissions of air pollutants and $\mathrm{CO}_{2}$ in China from 2010 to 2017.

\begin{tabular}{|c|c|c|c|c|c|c|c|c|c|c|c|}
\hline Year & $\mathrm{SO}_{2}{ }^{\mathrm{a}}$ & $\mathrm{NO}_{x}$ & NMVOC & $\mathrm{NH}_{3}$ & $\mathrm{CO}$ & $\mathrm{TSP}^{\mathrm{b}}$ & $\mathrm{PM}_{10}$ & $\mathrm{PM}_{2.5}$ & $\mathrm{BC}$ & $\mathrm{OC}$ & $\mathrm{CO}_{2}{ }^{\mathrm{c}}$ \\
\hline Power & 7.8 & 8.6 & 0.1 & 0.0 & 3.8 & 1.7 & 1.3 & 0.8 & 0.0 & 0.0 & 2864.8 \\
\hline Industry & 16.4 & 9.1 & 7.9 & 0.3 & 79.7 & 24.7 & 9.6 & 6.1 & 0.6 & 0.6 & 4914.3 \\
\hline Residential & 3.4 & 1.0 & 5.0 & 0.4 & 70.9 & 5.3 & 4.8 & 4.3 & 0.8 & 2.5 & 567.8 \\
\hline Transportation & 0.2 & 7.7 & 6.1 & 0.0 & 32.0 & 0.6 & 0.5 & 0.5 & 0.3 & 0.1 & 682.5 \\
\hline Agriculture & 0.0 & 0.0 & 0.0 & 9.5 & 0.0 & 0.0 & 0.0 & 0.0 & 0.0 & 0.0 & 0.0 \\
\hline Solvent use & 0.0 & 0.0 & 6.9 & 0.0 & 0.0 & 0.0 & 0.0 & 0.0 & 0.0 & 0.0 & 0.0 \\
\hline 2010 & 27.8 & 26.5 & 25.9 & 10.2 & 186.4 & 32.2 & 16.3 & 11.8 & 1.7 & 3.2 & 9029.4 \\
\hline Power & 7.9 & 9.5 & 0.1 & 0.0 & 4.4 & 1.8 & 1.4 & 0.9 & 0.0 & 0.0 & 3365.2 \\
\hline Industry & 17.3 & 10.2 & 8.5 & 0.3 & 76.3 & 25.4 & 9.8 & 6.2 & 0.6 & 0.6 & 5354.7 \\
\hline Residential & 3.6 & 1.1 & 5.0 & 0.4 & 71.6 & 5.3 & 4.9 & 4.3 & 0.9 & 2.5 & 609.9 \\
\hline Transportation & 0.3 & 8.0 & 5.8 & 0.0 & 30.2 & 0.5 & 0.5 & 0.5 & 0.3 & 0.1 & 735.7 \\
\hline Agriculture & 0.0 & 0.0 & 0.0 & 9.8 & 0.0 & 0.0 & 0.0 & 0.0 & 0.0 & 0.0 & 0.0 \\
\hline Solvent use & 0.0 & 0.0 & 7.6 & 0.0 & 0.0 & 0.0 & 0.0 & 0.0 & 0.0 & 0.0 & 0.0 \\
\hline 2011 & 29.1 & 28.7 & 26.9 & 10.5 & 182.7 & 33.1 & 16.6 & 11.9 & 1.8 & 3.2 & 10065.5 \\
\hline Power & 6.9 & 9.1 & 0.1 & 0.0 & 4.5 & 1.7 & 1.3 & 0.9 & 0.0 & 0.0 & 3361.3 \\
\hline Industry & 17.6 & 10.5 & 8.9 & 0.3 & 74.0 & 25.5 & 9.7 & 6.1 & 0.6 & 0.6 & 5584.5 \\
\hline Residential & 3.7 & 1.1 & 5.0 & 0.4 & 72.4 & 5.4 & 4.9 & 4.4 & 0.9 & 2.5 & 652.1 \\
\hline Transportation & 0.3 & 8.5 & 5.6 & 0.0 & 29.4 & 0.6 & 0.5 & 0.5 & 0.3 & 0.1 & 802.2 \\
\hline Agriculture & 0.0 & 0.0 & 0.0 & 9.9 & 0.0 & 0.0 & 0.0 & 0.0 & 0.0 & 0.0 & 0.0 \\
\hline Solvent use & 0.0 & 0.0 & 8.5 & 0.0 & 0.0 & 0.0 & 0.0 & 0.0 & 0.0 & 0.0 & 0.0 \\
\hline 2012 & 28.5 & 29.2 & 28.1 & 10.7 & 180.2 & 33.2 & 16.5 & 11.9 & 1.8 & 3.2 & 10400.1 \\
\hline Power & 6.0 & 7.9 & 0.1 & 0.0 & 4.7 & 1.6 & 1.3 & 0.8 & 0.0 & 0.0 & 3431.0 \\
\hline Industry & 15.8 & 10.3 & 9.1 & 0.4 & 72.9 & 24.6 & 9.3 & 5.8 & 0.6 & 0.6 & 5569.9 \\
\hline Residential & 3.4 & 1.0 & 4.8 & 0.4 & 69.3 & 5.1 & 4.7 & 4.2 & 0.8 & 2.4 & 600.6 \\
\hline Transportation & 0.3 & 8.5 & 5.6 & 0.0 & 29.8 & 0.6 & 0.5 & 0.5 & 0.3 & 0.1 & 849.4 \\
\hline Agriculture & 0.0 & 0.0 & 0.0 & 9.8 & 0.0 & 0.0 & 0.0 & 0.0 & 0.0 & 0.0 & 0.0 \\
\hline Solvent use & 0.0 & 0.0 & 8.6 & 0.0 & 0.0 & 0.0 & 0.0 & 0.0 & 0.0 & 0.0 & 0.0 \\
\hline 2013 & 25.4 & 27.7 & 28.1 & 10.6 & 176.6 & 31.8 & 15.8 & 11.4 & 1.7 & 3.1 & 10450.9 \\
\hline Power & 4.9 & 6.2 & 0.1 & 0.0 & 4.5 & 1.4 & 1.1 & 0.7 & 0.0 & 0.0 & 3359.4 \\
\hline Industry & 12.1 & 10.0 & 9.2 & 0.3 & 65.4 & 20.3 & 8.1 & 5.2 & 0.5 & 0.5 & 5530.3 \\
\hline Residential & 3.1 & 0.9 & 4.5 & 0.4 & 66.7 & 4.8 & 4.4 & 3.9 & 0.8 & 2.2 & 620.1 \\
\hline Transportation & 0.3 & 8.1 & 5.1 & 0.0 & 27.2 & 0.5 & 0.5 & 0.5 & 0.3 & 0.1 & 864.0 \\
\hline Agriculture & 0.0 & 0.0 & 0.0 & 9.8 & 0.0 & 0.0 & 0.0 & 0.0 & 0.0 & 0.0 & 0.0 \\
\hline Solvent use & 0.0 & 0.0 & 10.1 & 0.0 & 0.0 & 0.0 & 0.0 & 0.0 & 0.0 & 0.0 & 0.0 \\
\hline 2014 & 20.4 & 25.3 & 29.1 & 10.5 & 163.8 & 27.0 & 14.1 & 10.3 & 1.6 & 2.8 & 10373.8 \\
\hline Power & 3.9 & 5.1 & 0.1 & 0.0 & 4.5 & 1.3 & 1.0 & 0.6 & 0.0 & 0.0 & 3318.7 \\
\hline Industry & 9.8 & 9.7 & 9.4 & 0.4 & 56.2 & 15.7 & 6.7 & 4.4 & 0.4 & 0.4 & 5450.0 \\
\hline Residential & 2.9 & 0.9 & 4.2 & 0.4 & 64.0 & 4.4 & 4.1 & 3.6 & 0.7 & 2.0 & 651.5 \\
\hline Transportation & 0.3 & 8.0 & 5.4 & 0.0 & 28.9 & 0.5 & 0.5 & 0.5 & 0.3 & 0.1 & 926.9 \\
\hline Agriculture & 0.0 & 0.0 & 0.0 & 9.7 & 0.0 & 0.0 & 0.0 & 0.0 & 0.0 & 0.0 & 0.0 \\
\hline Solvent use & 0.0 & 0.0 & 9.5 & 0.0 & 0.0 & 0.0 & 0.0 & 0.0 & 0.0 & 0.0 & 0.0 \\
\hline 2015 & 16.9 & 23.7 & 28.5 & 10.5 & 153.6 & 21.9 & 12.3 & 9.1 & 1.5 & 2.5 & 10347.2 \\
\hline Power & 2.7 & 4.6 & 0.1 & 0.0 & 4.6 & 1.3 & 1.0 & 0.6 & 0.0 & 0.0 & 3399.9 \\
\hline Industry & 7.7 & 9.3 & 9.3 & 0.3 & 50.8 & 12.1 & 5.6 & 3.7 & 0.3 & 0.3 & 5290.1 \\
\hline Residential & 2.7 & 0.9 & 3.9 & 0.3 & 60.4 & 4.0 & 3.7 & 3.3 & 0.7 & 1.9 & 661.9 \\
\hline Transportation & 0.3 & 7.7 & 5.0 & 0.0 & 26.2 & 0.5 & 0.5 & 0.5 & 0.3 & 0.1 & 938.8 \\
\hline Agriculture & 0.0 & 0.0 & 0.0 & 9.6 & 0.0 & 0.0 & 0.0 & 0.0 & 0.0 & 0.0 & 0.0 \\
\hline Solvent use & 0.0 & 0.0 & 10.1 & 0.0 & 0.0 & 0.0 & 0.0 & 0.0 & 0.0 & 0.0 & 0.0 \\
\hline 2016 & 13.4 & 22.5 & 28.4 & 10.3 & 141.9 & 17.9 & 10.8 & 8.1 & 1.3 & 2.3 & 10290.6 \\
\hline Power & 1.8 & 4.2 & 0.1 & 0.0 & 4.8 & 1.3 & 1.0 & 0.6 & 0.0 & 0.0 & 3619.2 \\
\hline Industry & 6.0 & 9.2 & 9.7 & 0.3 & 49.2 & 11.1 & 5.2 & 3.5 & 0.3 & 0.3 & 5161.0 \\
\hline Residential & 2.4 & 0.8 & 3.6 & 0.3 & 57.0 & 3.7 & 3.4 & 3.0 & 0.6 & 1.7 & 676.5 \\
\hline Transportation & 0.3 & 7.7 & 4.8 & 0.0 & 25.2 & 0.6 & 0.6 & 0.5 & 0.3 & 0.1 & 977.6 \\
\hline Agriculture & 0.0 & 0.0 & 0.0 & 9.6 & 0.0 & 0.0 & 0.0 & 0.0 & 0.0 & 0.0 & 0.0 \\
\hline Solvent use & 0.0 & 0.0 & 10.4 & 0.0 & 0.0 & 0.0 & 0.0 & 0.0 & 0.0 & 0.0 & 0.0 \\
\hline 2017 & 10.5 & 22.0 & 28.6 & 10.3 & 136.2 & 16.7 & 10.2 & 7.6 & 1.3 & 2.1 & 10434.3 \\
\hline (2013-2010) / 2010 & $-9 \%$ & $5 \%$ & $9 \%$ & $4 \%$ & $-5 \%$ & $-1 \%$ & $-3 \%$ & $-4 \%$ & $1 \%$ & $-3 \%$ & $16 \%$ \\
\hline$(2017-2013) / 2013$ & $-59 \%$ & $-21 \%$ & $2 \%$ & $-3 \%$ & $-23 \%$ & $-48 \%$ & $-36 \%$ & $-33 \%$ & $-28 \%$ & $-32 \%$ & $0 \%$ \\
\hline (2017-2010) / 2010 & $-62 \%$ & $-17 \%$ & $11 \%$ & $1 \%$ & $-27 \%$ & $-48 \%$ & $-38 \%$ & $-35 \%$ & $-27 \%$ & $-35 \%$ & $16 \%$ \\
\hline
\end{tabular}

a The unit of emissions is Tg. ${ }^{\mathrm{b}}$ TSP is the particulate matter with an aerodynamic diameter of $100 \mu \mathrm{m}$ or less. ${ }^{\mathrm{c}} \mathrm{CO}_{2}$ from fossil fuel use and industrial processes. 
have remained constant because agriculture and rural activities showed small interannual variations.

\subsection{Drivers of China's emissions}

The effect of air pollution control can partially or totally offset the additional emissions caused by growing activity rates, and the combination of pollution control and activity growth entirely determines China's emission pathways (Fig. 5). Based on the drivers of emissions, we can classify air pollutants into two categories, namely, activity-driven increasing pollutants and pollution control-driven decreasing pollutants (Fig. 5). NMVOCs and $\mathrm{NH}_{3}$ belong to the former category. Their emissions have continued to increase at a constant rate from 2010 to 2017, primarily driven by activity growth. Assuming that activity rates are frozen at their 2010 levels (Fig. 3), the NMVOC emissions could decrease by $21 \%$ from 2010 to 2017 due to the emission controls on residential and transport sectors. These emission reductions were far outweighed by the growing use of solvent for paints, coatings, and chemical industry, which consequently drove up their total emissions. The solvent used for paints increased by $110 \%$ from 2010 , which is attributed to the increasing demand to coat buildings, cars, and machinery due to the rapid increase in the area of newly built houses $(+52 \%)$ and the production of vehicles $(+54 \%)$. The solvent used in chemical industry also rose at a fast rate due to the increase in industrial production (e.g., ethylene production grew by $28 \%$ since 2010), which makes them the second largest contributor to NMVOC growth after paints. For $\mathrm{NH}_{3}$, the lack of control measures has caused its emissions to correlate well with activity; thus, its emissions do not decline, unlike the regulated pollutants that have experienced progressive emission control.

The other air pollutants followed distinct emission pathways before and after 2013 (Fig. 5). According to our estimates the emissions of these pollutants slightly increased (e.g., $\mathrm{SO}_{2}$ and $\mathrm{NO}_{x}$ ) or remained flat (e.g., $\mathrm{CO}$ and particulate matter) during 2010-2013 because emission mitigation just counterbalanced the additional emissions caused by growing activities. China's fuel combustion increased by $15.2 \%$ from 2010 to 2013 (Fig. 6), and its industrial production increased by $14-35 \%$ in different industries. During this period, China's clean air actions mainly focused on upgrading emission standards for the power and industrial sectors. These measures effectively offset the growth in activities but were not stringent enough to reverse the growing trends in emissions; therefore, air pollutant emissions remained stable from 2010 to 2013.

After 2013, emissions of all air pollutants except NMVOCs and $\mathrm{NH}_{3}$ are found to have reduced as a result of pollution controls. China's fuel combustion and industrial production have flattened out since 2013 (Fig. 6), while high-efficiency mitigation measures have been increasingly implemented in all emission source sectors, as required by the Clean Air Action. Scenario analysis suggests that the effect of pollution control rapidly removes air pollutants and consequently drives down China's emissions (Fig. 3). Assuming that pollution control is frozen at 2010 levels, $\mathrm{SO}_{2}$ emissions in 2017 could increase by $167 \%$ compared to the actual data, $\mathrm{NO}_{x}$ and TSP emissions could increase by $38 \%$ and $111 \%$, respectively, and other pollutants could see increases of $23-66 \%$. The different reduction rates of air pollutant emissions are determined by the source sector distributions and emission mitigation efforts of each sector. For example, this decrease is most notable for $\mathrm{SO}_{2}$ (emissions are estimated to have decreased by $59 \%$ from 2013 to 2017) because the dominant source sectors (i.e., power and industry) both significantly reduced their emissions. The decrease in emissions is smallest for $\mathrm{NO}_{x}(21 \%$ of emissions cut from 2013 to 2017 based on the analysis) because the power sector was the major contributor to emission reduction but only accounted for one-third of total emissions. To understand the underlying drivers of emission reduction, we decompose the avoided emissions due to pollution control (i.e., the sum of contributions from $\boldsymbol{x}, \mathbf{E}$, and $\boldsymbol{\eta}$ ) into sectors (Fig. 7) to identify the main drivers underlying key source categories. We select the year of 2017, which exhibited the largest reduction in emissions according to our calculations, to perform this analysis.

1. The power sector. The generation of electricity from hydrocarbon fuels in China has increased by $33 \%$ since 2010, which has led to increases of $1.2 \mathrm{Tg} \mathrm{\textrm {SO } _ { 2 }}$ and $1.7 \mathrm{Tg} \mathrm{NO}_{x}$ in 2017 compared with their levels in 2010 (Fig. 7). Mitigation efforts have yielded reductions of 7.1 Tg $\mathrm{SO}_{2}$ and $6.1 \mathrm{Tg} \mathrm{NO}_{x}$ and thus totally offset the emissions caused by growing activities. The reduction of emissions was achieved through the ultralow emission standard. To fulfill the stringent standards, flue gas desulfurization (FGD) and selective catalytic reduction (SCR) systems have been increasingly installed at utilities in coal-fired power plants, with penetration rates reaching $>95 \%$ in 2017. Of the current power plants, $71 \%$ have operated close to the design performance of ultralow emission levels (China, 2018).

2. The industrial sector. Mitigation measures have yielded reductions of $9.5 \mathrm{Tg} \mathrm{SO}, 0.9 \mathrm{Tg} \mathrm{NO}, 38.1 \mathrm{Tg} \mathrm{CO}$, 3.4 Tg PM $2.5,0.3 \mathrm{Tg} \mathrm{BC}$, and $0.3 \mathrm{Tg} \mathrm{OC}$ from the industrial sector in 2017 compared with their levels in 2010 (Fig. 7). For $\mathrm{SO}_{2}$, shutting down small industrial boilers and cleaning larger ones have contributed the most to emission reductions. In particular, small coal boilers $(\leq 7 \mathrm{MW})$ located in urban areas were eliminated by the end of 2017, and large boilers have extensively used sorbent injection technologies to remove $\mathrm{SO}_{2}$ from exhaust gases. For other pollutants, the most effective measures include strengthening industrial emission standards, eliminating outdated industrial capacity, and 

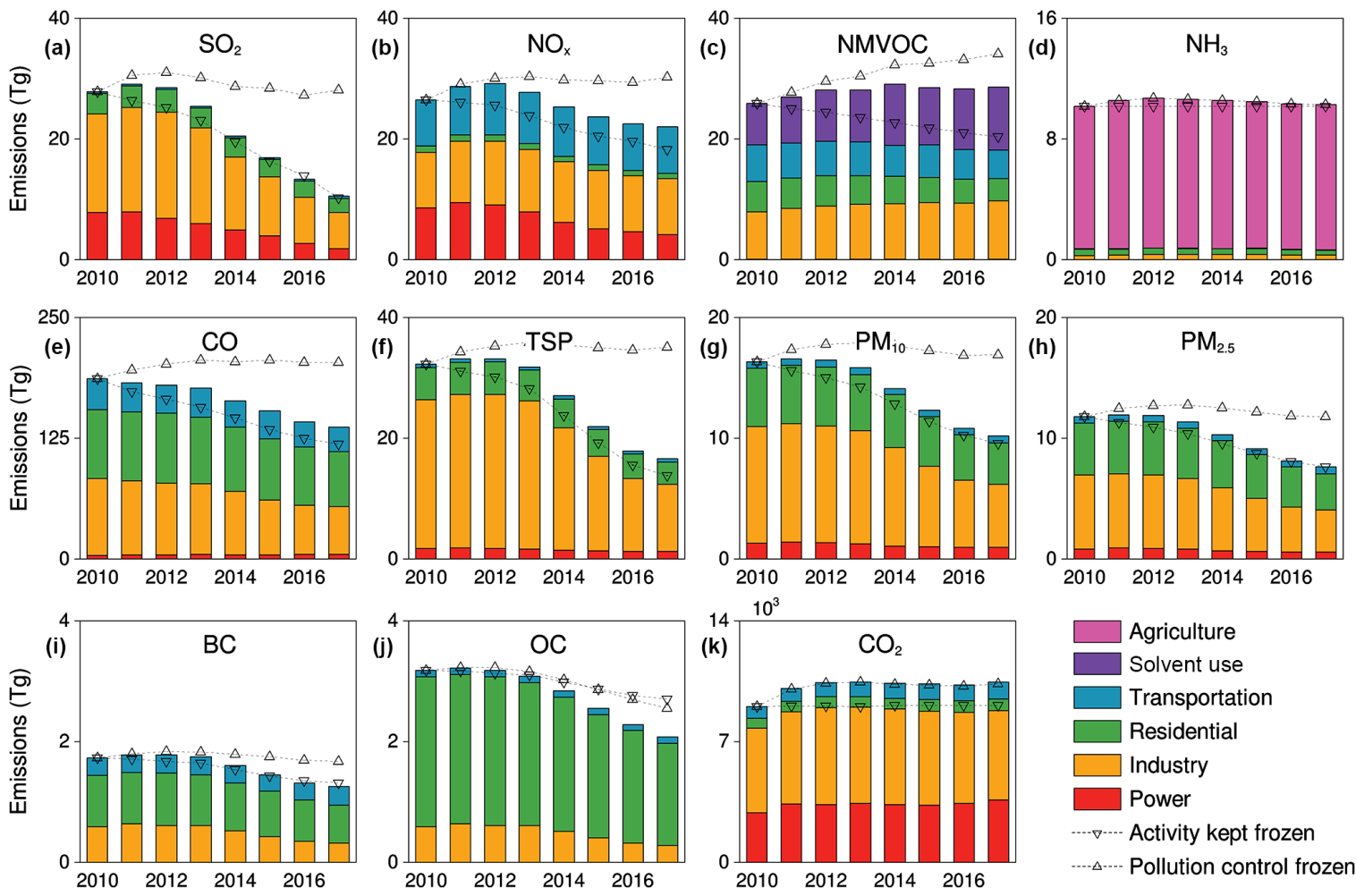

Figure 3. China's anthropogenic emissions by sector and year. The species plotted here include (a) $\mathrm{SO}_{2}$, (b) $\mathrm{NO}_{x}$, (c) $\mathrm{NMVOCs}$, (d) $\mathrm{NH}_{3}$, (e) $\mathrm{CO}$, (f) $\mathrm{TSP},(\mathbf{g}) \mathrm{PM}_{10}$, (h) $\mathrm{PM}_{2.5}$, (i) $\mathrm{BC}$, (j) $\mathrm{OC}$, and (k) $\mathrm{CO}_{2}$. Chinese emissions are divided into six source sectors (stacked column chart): power, industry, residential, transportation, agriculture, and solvent use. Besides the actual emissions data, two emission scenarios are presented to provide emission trajectories when assuming activity (inverted triangle) or pollution control (upright triangle) frozen at 2010 levels.

phasing out small high-emitting factories. The improvements in combustion efficiency and oxygen blast furnace gas recycling are the largest drivers of declining $\mathrm{CO}$ emissions, and the wide use of high-efficiency dust collectors (e.g., electrostatic precipitators and fabric filters) in manufacturing industries has successfully removed particulate matter. In addition, the desulfurization of sinter plant gases accounts for $8 \%$ of $\mathrm{SO}_{2}$ emission reductions, and denitrification in cement kilns accounts for $6 \%$ of $\mathrm{NO}_{x}$ emission reductions. The lowsulfur, low-ash coals resulting from fuel quality improvements have also helped reduce $\mathrm{SO}_{2}$ and particulate emissions.

3. The residential sector. The emission reductions achieved by the residential sector are primarily driven by the decrease in activities mainly caused by replacing coal with natural gas and electricity (Fig. 7), which yielded reductions of $13.5 \mathrm{Tg} \mathrm{CO}, 1.0 \mathrm{Tg} \mathrm{PM}_{2.5}, 0.1 \mathrm{Tg}$ $\mathrm{BC}$, and $0.7 \mathrm{Tg}$ OC in 2017 compared with their 2010 levels. Additionally, pollution controls caused additional reductions of $0.5 \mathrm{Tg} \mathrm{CO}, 0.3 \mathrm{Tg} \mathrm{PM}_{2.5}, 0.1 \mathrm{Tg}$ $\mathrm{BC}, 0.1 \mathrm{Tg} \mathrm{OC}$, and $1.0 \mathrm{Tg} \mathrm{\textrm {SO } _ { 2 }}$. The decreases in activity rates reflect both long-term changes in fuel mix- tures, i.e., from traditional biofuels to commercial energy, and short-term measures to replace coal with clean energy. Pollution control policies have promoted the use of clean stoves and the switch from raw coal to clean coal briquettes with lower levels of sulfur and ash.

4. The transportation sector. Pollution controls on the transportation sector have exactly counterbalanced the growing emissions due to vehicle growth (Fig. 7) China's vehicle ownership reached 209 million in 2017; this value is 2.7 times larger than its 2010 value. Growing activities yielded increases of $22.2 \mathrm{Tg} \mathrm{CO}, 3.6 \mathrm{Tg}$ NMVOCs, and $1.4 \mathrm{Tg} \mathrm{NO}$ in 2017 compared with their 2010 levels, while pollution control measures have yielded reductions of $29.0 \mathrm{Tg} \mathrm{CO}, 4.8 \mathrm{Tg}$ NMVOCs, and $1.3 \mathrm{Tg} \mathrm{NO}$. The reduction of emissions is mainly achieved through fleet turnover, which means that old vehicles are being replaced by newer, cleaner models subjected to tougher emission standards. China has scrapped all the old vehicles that do not meet the more stringent emission standards, i.e., "yellow label" vehicles, by the end of 2017. The number of vehicles scrapped in each province is recorded by the local government, and these scrapped vehicles are banned from 

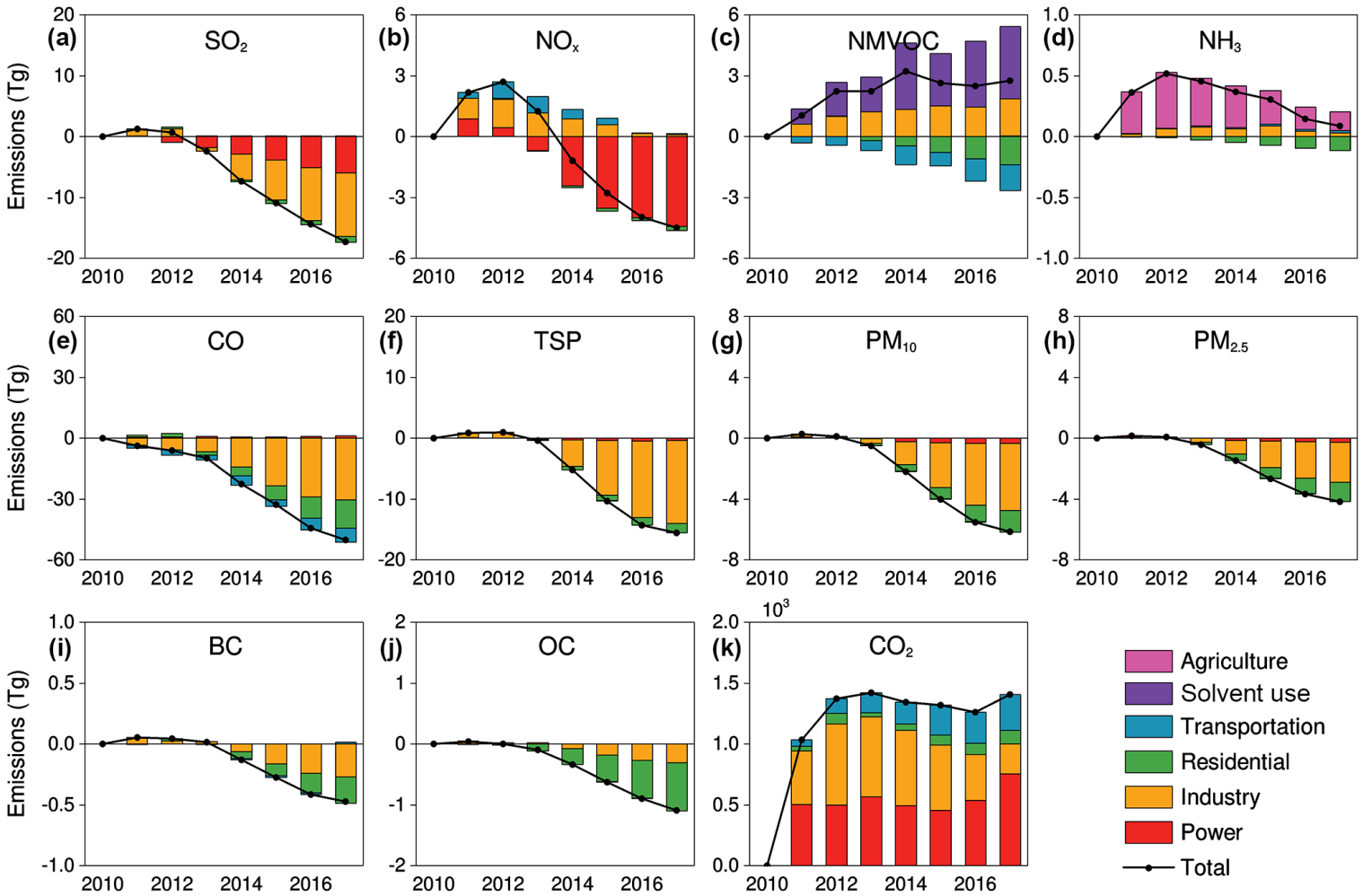

Figure 4. Changes in China's emissions by sector and year. The species plotted here include (a) $\mathrm{SO}_{2}$, (b) $\mathrm{NO}_{x}$, (c) $\mathrm{NMVOCs}$, (d) $\mathrm{NH}_{3}$, (e) $\mathrm{CO}$, (f) $\mathrm{TSP},(\mathbf{g}) \mathrm{PM}_{10}$, (h) $\mathrm{PM}_{2.5}$, (i) $\mathrm{BC}$, (j) $\mathrm{OC}$, and (k) $\mathrm{CO}_{2}$. The 2010 emissions are subtracted from the emission data for each year to represent the additional emissions compared to 2010 levels. The emission changes are shown by sector (stacked column chart) and as national totals (black curve).

roads and sent to wrecking yard for recycling. Consequently, the estimated share of fuel consumption by Euro 4 and Euro 5 vehicles increased from $2 \%$ in 2010 to $66 \%$ in 2017. The effects of these changes on reducing particulate emissions are smaller because transport contributes only a small fraction of total particulate emissions. For NMVOCs, the transport sector is the only sector that has seen a deep cut in emissions. More than $80 \%$ of NMVOC emission reductions are achieved from tailpipe exhaust sources, which have caused evaporative emissions to be the primary source ( $>60 \%$ ) of the remaining NMVOC emissions from transport.

\subsection{Comparison with observations and implication for uncertainties}

Comparison of trends in $\mathrm{PM}_{2.5}$ precursor emissions with satellite and ground-based $\mathrm{PM}_{2.5}$ concentrations are presented in Fig. 8a. All data are normalized to the year 2013 because it is the only year that all data are available. Satellitederived $\mathrm{PM}_{2.5}$ concentrations presented a relatively flat trend during 2010 and 2013 (e.g., Fontes et al., 2017; Liang et al., 2018; Lin et al., 2018), corresponding to small variations in emissions of different precursors estimated for the same period. Satellite-based $\mathrm{PM}_{2.5}$ concentrations over China decreased by $18 \%$ from 2013 to 2015 (Lin et al., 2018), in good agreement with the trend in surface $\mathrm{PM}_{2.5}$ concentrations over 74 cities. During 2013-2017, surface $\mathrm{PM}_{2.5}$ concentrations over 74 cites decreased by $35 \%$, while emissions of $\mathrm{PM}_{2.5}$ precursors over China presented various changing rates. We estimate a faster decrease in $\mathrm{SO}_{2}$ emissions than the observed surface $\mathrm{PM}_{2.5}$ concentrations, while the estimated decreasing rates of $\mathrm{NO}_{x}$ and $\mathrm{NH}_{3}$ emissions were slower than the observed $\mathrm{PM}_{2.5}$ concentrations. This phenomenon was qualitatively confirmed by an observed large decrease in sulfate and increased relative contribution of nitrate in $\mathrm{PM}_{2.5}$ compositions from 2013 to 2017 (Shao et al., 2018). However, the quantitative relationship between $\mathrm{PM}_{2.5}$ concentrations and precursor emissions will require further studies with chemical transport modeling.

Trends in $\mathrm{NO}_{x}$ and $\mathrm{SO}_{2}$ emissions are generally consistent with satellite- and ground-based observations during 2010 2017 (Fig. 8b and Table 2). Specifically, rapid decreases in $\mathrm{SO}_{2}$ and $\mathrm{NO}_{x}$ emissions after 2013 are confirmed by satellite-based observations. We estimate that $\mathrm{NO}_{x}$ and $\mathrm{SO}_{2}$ emissions in eastern China decreased by $21 \%$ and $59 \%$ during 2013-2017 respectively, lower than the $30 \%$ and $73 \%$ decreases in OMI observed $\mathrm{NO}_{2}$ and $\mathrm{SO}_{2}$ columns for the 

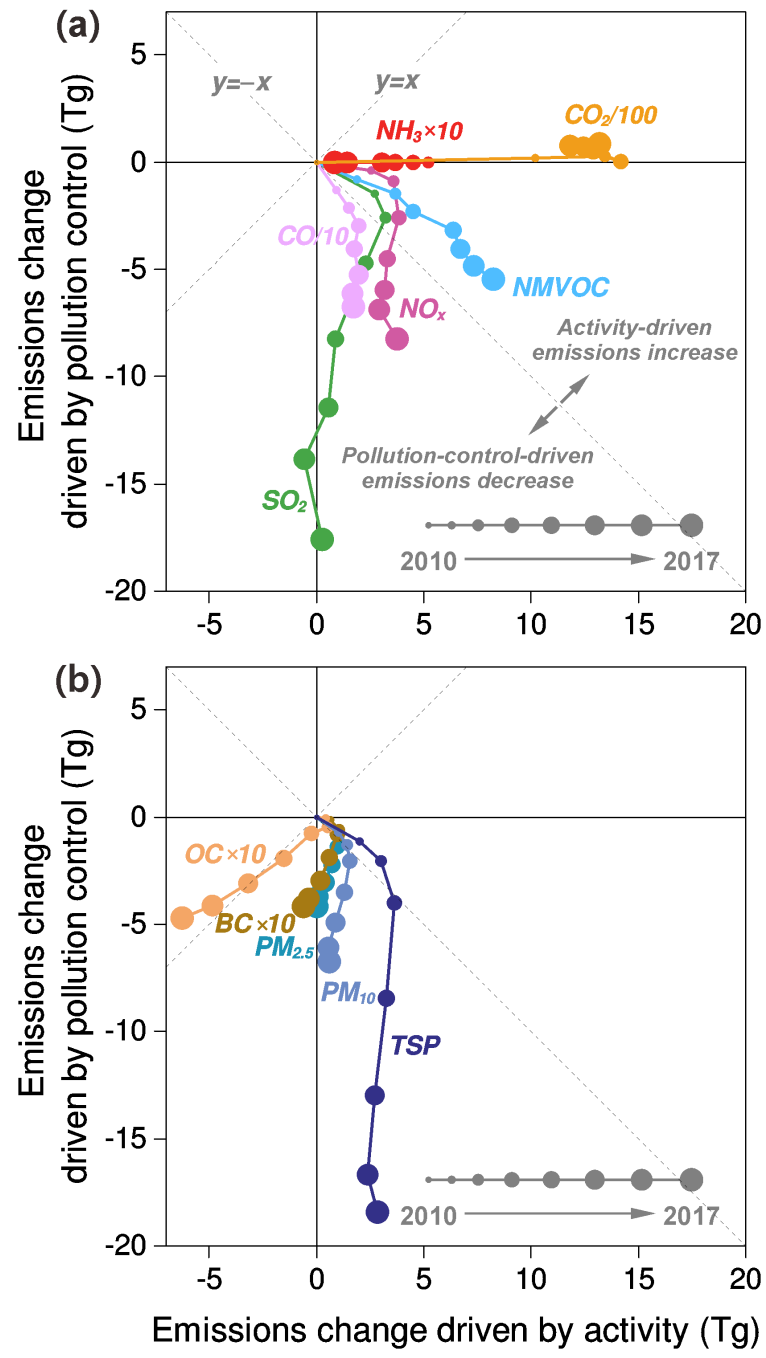

Figure 5. China's emission pathways from 2010 to 2017. Gaseous pollutants are plotted in (a), and particles are plotted in (b). For each pollutant, the years (circle) are plotted according to the emission changes caused by activity ( $A$ in Eq. 2, $x$ axis) and pollution control (the sum of $\boldsymbol{x}, \mathbf{E}$, and $\boldsymbol{\eta}$ in Eq. 2, $y$ axis). Please refer to Fig. S1 in the Supplement for decomposition analysis results of $A, \boldsymbol{x}, \mathbf{E}$, and $\eta$. The intersecting lines $y=x$ and $y=-x$ divide the coordinate plane into four sections. Any point in the section on the right side of the two lines reflects increasing emissions due to activity growth, and the points in the section below the two lines reflect decreasing emissions driven by pollution control.

same region and time period. Surface $\mathrm{SO}_{2}$ concentrations decreased by $57 \%$ over eastern China for the period of 20132017, in good agreement with the estimated emission trend. In contrast, surface $\mathrm{NO}_{2}$ concentrations only decreased by $9 \%$ for the same time, significantly lower than the estimated trend in $\mathrm{NO}_{x}$ emissions.

Different trends between emissions and concentrations could be attributed to many factors. First, temporal and spatial patterns of emissions and concentrations are impacted by

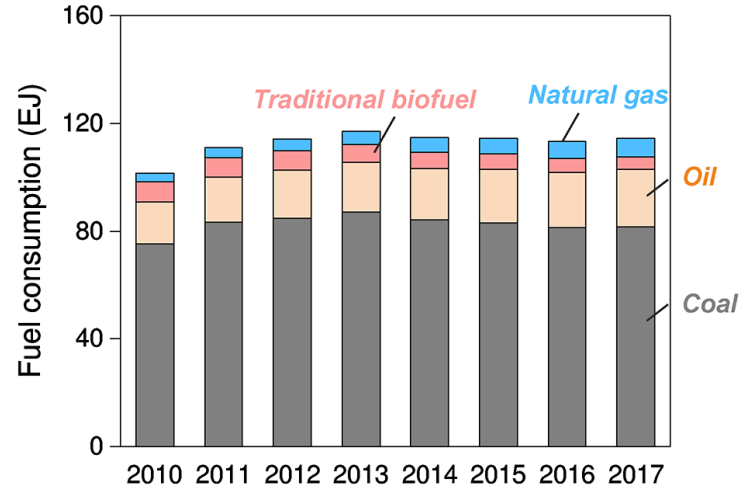

Figure 6. Energy consumption of hydrocarbon fuels from 2010 to 2017. Coal includes all coal-based fuels, and oil includes all oilbased fuels. Traditional biofuel includes crop residual and wood.

variations in meteorology, atmospheric transport, and chemical reactions. Interannual variabilities can result in remarkable variations in column and surface concentrations (Uno et al., 2007), which may partly explain the disagreement between changes in emissions and observations for a signal year (e.g., the year 2011 in Fig. 8b). Surface observations are more sensitive to surface emissions than highstack emissions and satellite-based column observations are more visible to high-stack emissions due to different transport patterns, in which both will contribute to the differences when comparing trends. In addition, chemical partitioning of $\mathrm{NO}_{x}$ into $\mathrm{NO}_{2}$ may also contribute to discrepancies between trends in emissions and observations (Lamsal et al., 2011, Valin et al., 2011). Taking the above factors into account, inverse modeling (IM) approaches were developed to derive top-down emissions constrained by observations. Table 2 presented recently published estimates on top-down emission trends over China using IM approaches. As shown in Table 2, the discrepancies between bottom-up and top-down emission estimates are not always narrowed, indicating uncertainties from other aspects might exist.

Second, uncertainties in observations can also contribute to the discrepancies. In situ observations are usually thought to be more accurate. However, surface $\mathrm{NO}_{2}$ concentrations obtained from national monitoring networks relied on chemiluminescence measurements, which can significantly overestimate $\mathrm{NO}_{2}$ concentrations (Lamsal et al., 2010) and then contribute to discrepancies between emissions and surface observations. Satellite retrievals are subject to larger uncertainties, for instance, tropospheric $\mathrm{SO}_{2}$ columns are quite uncertain due to difficulties in isolating anthropogenic $\mathrm{SO}_{2}$ signals from ozone and volcanic $\mathrm{SO}_{2}$ (Krotkov et al., 2006). Most uncertainties in satellite retrievals are systematic and canceled out when trends are compared. However, influences of aerosols on satellite $\mathrm{NO}_{2}$ retrievals (Lin et al., 2015) may impact the reliability of the $\mathrm{NO}_{2}$ column trend due to the large decrease in aerosol concentrations over the discussed 

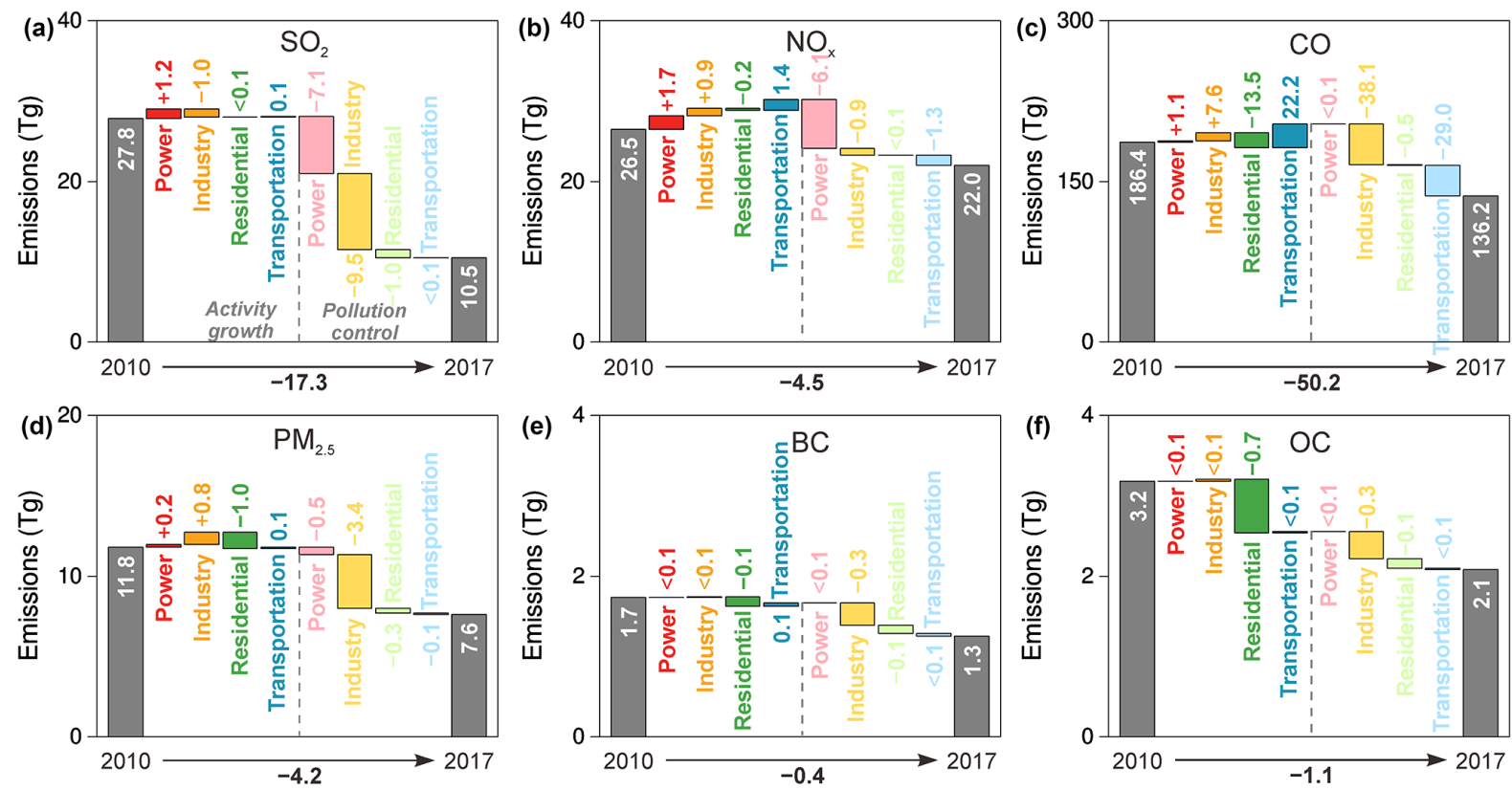

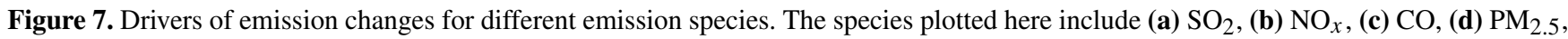
(e) BC, and (f) OC. For each pollutant, the changes in emissions from 2010 to 2017 (bar) are decomposed into drivers of activity growth ( $A$ in Eq. 2) and pollution control (the sum of $\boldsymbol{x}, \mathbf{E}$, and $\boldsymbol{\eta}$ in Eq. 2) by source sector.

Table 2. Comparison of trends in bottom-up emission inventory, satellite-based observations, and top-down emission estimates since 2010.

\begin{tabular}{|c|c|c|c|c|c|c|c|}
\hline Pollutant & Study & Method $^{\mathrm{a}}$ & Data & Region $^{b}$ & Period & $\begin{array}{r}\text { Percent } \\
\text { change } \\
(\%)\end{array}$ & $\begin{array}{r}\text { Percent } \\
\text { change of } \\
\text { emissions in } \\
\text { this study } \\
(\%)\end{array}$ \\
\hline \multirow[t]{5}{*}{$\mathrm{SO}_{2}$} & Krotkov et al. (2016) & SAT & $\mathrm{OMI} \mathrm{SO}_{2}$ columns & E China & 2010-2015 & -48 & -45 \\
\hline & van der A et al. (2017) & SAT & $\mathrm{OMI} \mathrm{SO}_{2}$ columns & China & 2010-2015 & -34 & -39 \\
\hline & C. Li et al. (2017) & SAT & $\mathrm{OMI} \mathrm{SO}_{2}$ columns & China & 2010-2016 & -68 & -52 \\
\hline & C. Li et al. (2017) & $\mathrm{IM}$ & $\begin{array}{l}\mathrm{SO}_{2} \text { emissions inferred } \\
\text { from } \mathrm{OMI} \mathrm{SO}_{2} \text { columns }\end{array}$ & China & 2010-2016 & -71 & -52 \\
\hline & Koukouli et al. (2018) & IM & $\begin{array}{l}\mathrm{SO}_{2} \text { emissions inferred } \\
\text { from } \mathrm{OMI} \mathrm{SO}_{2} \text { columns }\end{array}$ & China & 2010-2015 & -27 & -39 \\
\hline \multirow[t]{5}{*}{$\mathrm{NO}_{x}$} & Krotkov et al. (2016) & SAT & $\mathrm{OMI} \mathrm{NO}_{2}$ columns & E China & 2010-2015 & -22 & -14 \\
\hline & Liu et al. (2016) & SAT & OMI $\mathrm{NO}_{2}$ columns & E China & 2010-2015 & -22 & -14 \\
\hline & de Foy et al. (2016) & SAT & OMI $\mathrm{NO}_{2}$ columns & China & 2010-2015 & -12 & -10 \\
\hline & van der A et al. (2017) & IM & $\begin{array}{l}\mathrm{NO}_{x} \text { emissions inferred } \\
\text { from } \mathrm{OMI} \mathrm{NO}_{2} \text { columns }\end{array}$ & E China & 2010-2015 & -8 & -14 \\
\hline & Miyazaki et al. (2017) & IM & $\begin{array}{l}\mathrm{NO}_{x} \text { emissions inferred } \\
\text { from } \mathrm{OMI} \mathrm{NO}_{2} \text { columns }\end{array}$ & China & $2010-2015$ & -4 & -10 \\
\hline $\mathrm{NH}_{3}$ & Warner et al. (2017) & SAT & AIRS $\mathrm{NH}_{3} \mathrm{VMR}^{\mathrm{c}}$ & China & 2010-2016 & 9 & 1 \\
\hline \multirow[t]{2}{*}{$\mathrm{CO}$} & Jiang et al. (2017) & \multirow{2}{*}{ IM } & $\mathrm{CO}$ emissions inferred from & E China & 2010-2015 & $-13 \sim-9$ & -18 \\
\hline & Zheng et al. (2018) & & MOPITT CO columns & China & 2010-2016 & -25 & -24 \\
\hline
\end{tabular}

${ }^{a}$ SAT: satellite-based observations; IM: inverse modeling. ${ }^{b}$ E China: eastern China. ${ }^{c}$ VMR: volume mixing ratio. 

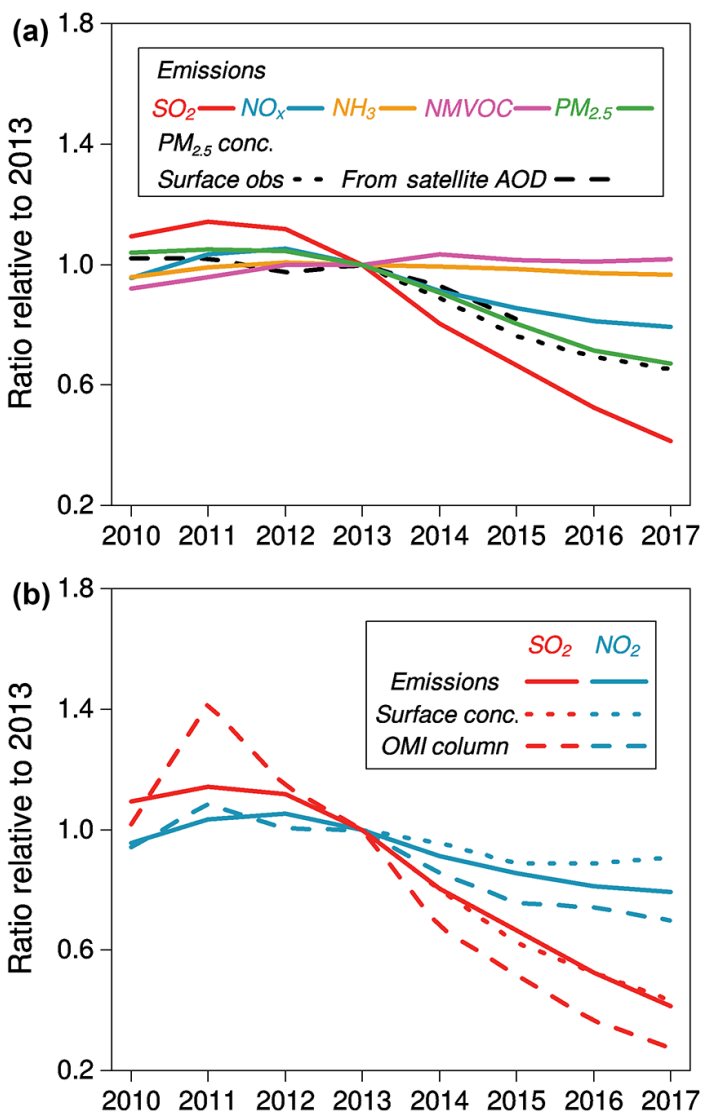

Figure 8. Emission trends compared with satellite- and groundbased observations. The satellite-retrieved $\mathrm{PM}_{2.5}$ concentrations (black, the dashed curve in a) (Lin et al., 2018) are compared with emission trends of $\mathrm{PM}_{2.5}$ precursors in (a). The 2010-2017 trends in $\mathrm{SO}_{2}$ (red, the solid curve in $\mathbf{b}$ ) and $\mathrm{NO}_{x}$ (blue, the solid curve in b) emissions are compared with $\mathrm{OMI} \mathrm{SO}_{2}$ (red, the dashed curve in b) and $\mathrm{NO}_{2}$ (blue, the dashed curve in b) tropospheric columns for eastern China, respectively. Eastern China here includes the provinces of Beijing, Tianjin, Hebei, Shanxi, Shaanxi, Shandong, Henan, Hubei, Anhui, Jiangsu, Shanghai, and Zhejiang. The 20132017 trends in ground-based observations of $\mathrm{SO}_{2}$ (red, the dotted curve in b), $\mathrm{NO}_{2}$ (blue, the dotted curve in $\mathbf{b}$ ), and $\mathrm{PM}_{2.5}$ (black, the dotted curve in a) are also presented. Data are normalized by dividing the value of each year by their corresponding value in 2013 .

period. $\mathrm{SO}_{2}$ columns are less sensitive to small and nearsurface emissions (C. Li et al., 2017), which may lead to an underestimation of the $\mathrm{SO}_{2}$ budget in China for most recent years and a disagreement between emission and $\mathrm{SO}_{2}$ column trends when high-stack emissions (e.g., power plants) were significantly reduced.

Last but not least, emissions estimates are uncertain due to incomplete knowledge of underlying data (Zhao et al., 2011; M. Li et al., 2017b). Similar magnitudes of uncertainties are expected considering previous work (e.g., Zhang et al., 2009; Lei et al., 2011; Lu et al., 2011; M. Li et al., 2017b) since similar methodologies and data sources are used. In gen- eral, uncertainties are smaller for species whose emissions are dominant by large sources (e.g., $\mathrm{SO}_{2}$ and $\mathrm{NO}_{x}$ ) but larger for species whose emissions are mainly contributed by scattered emitting sources (e.g., BC and OC). Many of the uncertainties in bottom-up emissions are also systematic and may have less impact on emission trends (Lu et al., 2011), but non-compliance with regulations due to lack of inspection will lead to differences between estimated and realworld efficiencies of emission control facilities (e.g., Wang et al., 2015) and impact the validity of estimated emission trend. Specifically, the effectiveness of the measures targeting the small and scattered emitting sources (e.g., phase out small high-emitting factories and eliminate small coal-fired industrial boilers) are difficult to validate, which may lead to higher uncertainty ranges in emission estimates for most recent years.

\section{Concluding remarks}

From 2010 to 2017, China reduced its anthropogenic emissions by $62 \%$ for $\mathrm{SO}_{2}, 17 \%$ for $\mathrm{NO}_{x}, 27 \%$ for $\mathrm{CO}, 38 \%$ for $\mathrm{PM}_{10}, 35 \%$ for $\mathrm{PM}_{2.5}, 27 \%$ for $\mathrm{BC}$, and $35 \%$ for $\mathrm{OC}$ according to our estimates. Compared to observations, the trends in $\mathrm{NO}_{x}$ and $\mathrm{SO}_{2}$ emissions are broadly consistent with OMI satellite and ground-based measurement, and the emissions trends of $\mathrm{PM}_{2.5}$ precursors agree well with changes in $\mathrm{PM}_{2.5}$ compositions over China. Some differences between emissions trends and observations could be attributed to uncertainties in atmospheric measurement and emissions estimates, as well as the mismatch in their spatial-temporal patterns due to chemical processes in the atmosphere. Most of the emission reductions were achieved after 2013, and the index decomposition analysis confirms that emission control measures have been the dominant driver of this declining emission trend. Pollution controls on the power and industrial sectors are the most effective measures, which have contributed 56-94\% of total avoided emissions due to stringent mitigation policies, such as strengthening emission standards, eliminating outdated industrial capacity, and phasing out small high-emitting factories. Emissions from transport tend to remain flat because the effect of air pollution control is offset by the additional emissions from growing activities. The residential sector has reduced its emissions mainly through the substitution of clean fuels. From 2010 to 2017, NMVOC emissions are estimated to have increased by $11 \%$ and $\mathrm{NH}_{3}$ emissions flattened because China lacked effective emission control measures on NMVOCs and $\mathrm{NH}_{3}$ in current policies.

All these emissions reductions from 2010 to 2017 were driven by the objective to reduce $\mathrm{PM}_{2.5}$ pollution in China. For years after 2017, all cities that exceed the $35 \mu \mathrm{g} \mathrm{m}^{-3}$ annual standard are further required to reduce annual average $\mathrm{PM}_{2.5}$ concentrations by $18 \%$ in 2020 compared to their 2015 levels. Since the annual average limit of $\mathrm{PM}_{2.5}$ is ex- 

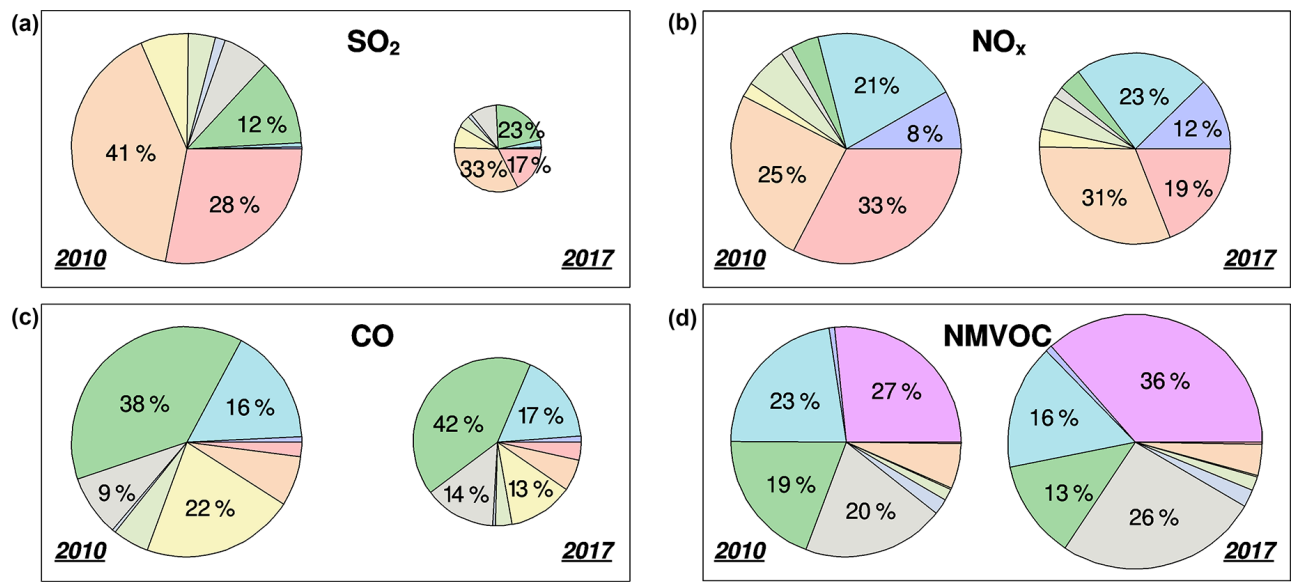

(d)

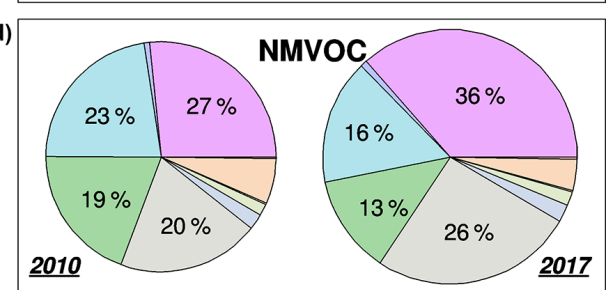

(e)

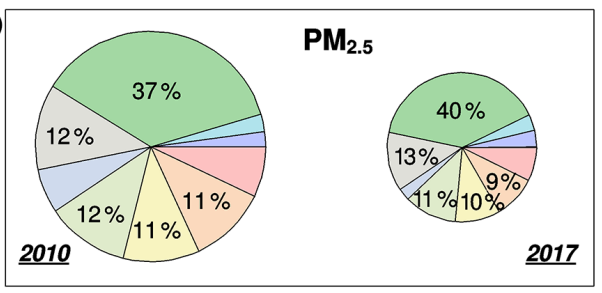

(f)
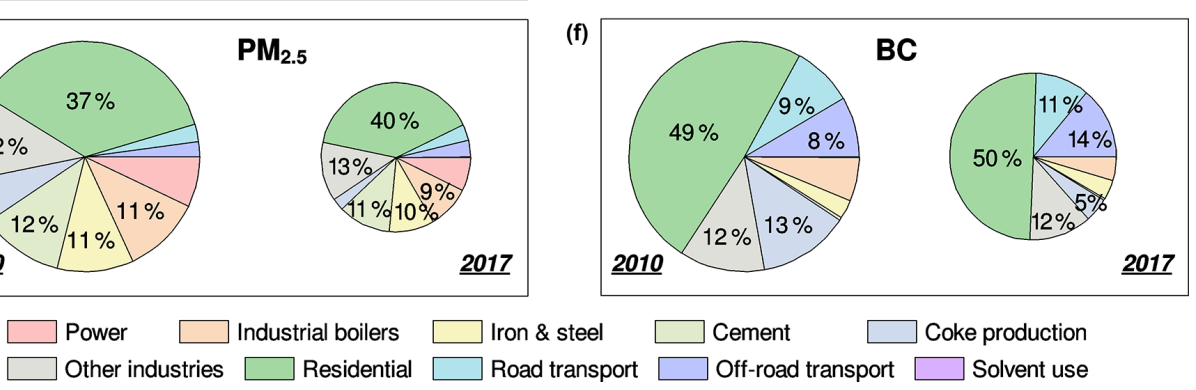

Figure 9. Changes in emission percentages across source sectors from 2010 to 2017. The species plotted here include (a) $\mathrm{SO}_{2}$, (b) $\mathrm{NO}_{x}$, (c) CO, (d) NMVOCs, (e) $\mathrm{PM}_{2.5}$, and (f) BC. For each pollutant, the relative change in the radius of the pie chart from 2010 to 2017 is proportional to the change in emissions.

ceeded in many Chinese cities currently, the 2020 air quality target will continue to drive down China's air pollutant emissions in the future. With emissions going down, the contributions of once-dominant source sectors have decreased, and emissions from other sources have gradually occupied larger proportions (Fig. 9). The change in the sectoral distribution of emissions indicates that it is paramount to shift policy focus to enable further emission reductions. China's clean air policies during 2013-2017 had limited effects on reducing emissions from the residential, off-road, vehicle evaporative, solvent use, and agricultural sectors; therefore, these sectors have significantly increased their contributions from 2010 to 2017 based on our analysis (Fig. 9). The residential sector is estimated to account for $23 \%-50 \%$ of $\mathrm{SO}_{2}$ and particulate emissions in 2017, comparable to or even larger than the emissions from the power and industrial sectors. The contribution of off-road transport to $\mathrm{NO}_{x}$ emissions is estimated to have increased from $8 \%$ to $12 \%$ (Fig. 9b) and thus ranked as the fourth largest single sector in 2017. For road transport, evaporation emissions of NMVOCs are larger than tailpipe emissions now because the tailpipe emissions reduced significantly from 2010 to 2017. A wide range of solvent-using activities drove up NMVOC emissions, therefore solvent use ranked as the largest source sector (Fig. 9d). The agricultural sector currently lacks targets, policies, and measures to control $\mathrm{NH}_{3}$ emissions. These less-controlled emission sources have large potential effects on China's 2020 air quality target. Thus, China needs to increase its focus on these sources from now on.

Data availability. The emission inventory data developed by this work are publically available from https://doi.org/10.6084/m9. figshare.c.4217624.v1 and http://www.meicmodel.org. A supplementary data file containing all underlying data for the figures of the paper is also provided in the Supplement. For the data used in this work, statements have been included about which data are publically available (accessed through references and links). The confidential information used in this study is a firm-level database for key industries in China, which are owned and managed by the Ministry of Ecology and Environment and not available to the public. The firm-level data are used to derive the penetration rates of different emission control technologies ( $C$ and $\eta$ in Eq. 1). The role of these confidential data in the estimates of emissions has been clarified in the main text.

Supplement. The supplement related to this article is available online at: https://doi.org/10.5194/acp-18-14095-2018-supplement.

Author contributions. QZ and KH conceived the study. BZ, DT, ML, and FL conducted estimates of China's emissions. $\mathrm{CH}$, GG, 
HL, XL, LP, JQ, LY, YZ, HZ, and YZ helped process the data needed by emission estimate. BZ performed the index decomposition analysis and interpreted the data. BZ and QZ wrote the paper with inputs from all coauthors.

Competing interests. The authors declare that they have no conflict of interest.

Acknowledgements. This work was supported by the National Key R\&D program (2016YFC0201506), the National Natural Science Foundation of China (41625020, 91744310, and 41571130035), and the public welfare program of China's Ministry of Environmental Protection (201509004)

Edited by: Neil Harris

Reviewed by: two anonymous referees

\section{References}

Boersma, K. F., Eskes, H. J., Dirksen, R. J., van der A, R. J., Veefkind, J. P., Stammes, P., Huijnen, V., Kleipool, Q. L., Sneep, M., Claas, J., Leitão, J., Richter, A., Zhou, Y., and Brunner, D.: An improved tropospheric $\mathrm{NO}_{2}$ column retrieval algorithm for the Ozone Monitoring Instrument, Atmos. Meas. Tech., 4, 19051928, https://doi.org/10.5194/amt-4-1905-2011, 2011.

China: Air quality targets set by the Action Plan have been fully realized, http://www.gov.cn/xinwen/2018-02/01/content_ 5262720.htm, last access: 30 September 2018

China State Council: Action Plan on Prevention and Control of Air Pollution, China State Council, Beijing, China, http: //www.gov.cn/zwgk/2013-09/12/content_2486773.htm (last access: 30 September 2018), 2013.

China State Council: The 13th Five-Year plan on energy saving and emissions reduction, China State Council, Beijing, China, http://www.gov.cn/zhengce/content/2017-01/05/content_ 5156789.htm (last access: 30 September 2018), 2016.

de Foy, B., Lu, Z., and Streets, D. G.: Satellite $\mathrm{NO}_{2}$ retrievals suggest China has exceeded its $\mathrm{NO}_{x}$ reduction goals from the twelfth Five-Year Plan, Scientific Reports, 6, 35912, https://doi.org/10.1038/srep35912, 2016.

Dietzenbacher, E. and Los, B.: Structural Decomposition Techniques: Sense and Sensitivity, Econ. Syst. Res., 10, 307-324, https://doi.org/10.1080/09535319800000023, 1998.

Fontes, T., Li, P., Barros, N., and Zhao, P.: Trends of $\mathrm{PM}_{2.5}$ concentrations in China: A long term approach, J. Environ. Manage., 196, 719-732, https://doi.org/10.1016/j.jenvman.2017.03.074, 2017.

Hoekstra, R. and van den Bergh, J. C. J. M.: Comparing structural decomposition analysis and index, Energ. Econ., 25, 39-64, https://doi.org/10.1016/S0140-9883(02)00059-2, 2003.

Hoesly, R. M., Smith, S. J., Feng, L., Klimont, Z., JanssensMaenhout, G., Pitkanen, T., Seibert, J. J., Vu, L., Andres, R. J., Bolt, R. M., Bond, T. C., Dawidowski, L., Kholod, N., Kurokawa, J.-I., Li, M., Liu, L., Lu, Z., Moura, M. C. P., O'Rourke, P. R., and Zhang, Q.: Historical (1750-2014) anthropogenic emissions of reactive gases and aerosols from the Com- munity Emissions Data System (CEDS), Geosci. Model Dev., 11, 369-408, https://doi.org/10.5194/gmd-11-369-2018, 2018.

Huo, H., Yao, Z., He, K., and Yu, X.: Fuel consumption rates of passenger cars in China: Labels versus real-world, Energ. Policy, 39, 7130-7135, https://doi.org/10.1016/j.enpol.2011.08.031, 2011.

Jiang, Z., Worden, J. R., Worden, H., Deeter, M., Jones, D. B. A., Arellano, A. F., and Henze, D. K.: A 15-year record of $\mathrm{CO}$ emissions constrained by MOPITT CO observations, Atmos. Chem. Phys., 17, 4565-4583, https://doi.org/10.5194/acp17-4565-2017, 2017

Koukouli, M. E., Theys, N., Ding, J., Zyrichidou, I., Mijling, B., Balis, D., and van der A, R. J.: Updated $\mathrm{SO}_{1} 112$ emission estimates over China using OMI/Aura observations, Atmos. Meas. Tech., 11, 1817-1832, https://doi.org/10.5194/amt11-1817-2018, 2018

Krotkov, N. A., Carn, S. A., Krueger, A. J., Bhartia, P. K., and Kai, Y.: Band residual difference algorithm for retrieval of $\mathrm{SO}_{2}$ from the aura ozone monitoring instrument (OMI), IEEE T. Geosci. Remote, 44, 1259-1266, https://doi.org/10.1109/TGRS.2005.861932, 2006.

Krotkov, A. N., Li, C., and Leonard, P.: OMI/Aura Sulfur Dioxide $\left(\mathrm{SO}_{2}\right)$ Total Column L3 1 day Best Pixel in 0.25 degree $\times 0.25$ degree V3, Greenbelt, MD, USA, Goddard Earth Sciences Data and Information Services Center (GES DISC), https://doi.org/10.5067/Aura/OMI/DATA3008 (last access: 30 September 2018), 2015.

Krotkov, N. A., McLinden, C. A., Li, C., Lamsal, L. N., Celarier, E. A., Marchenko, S. V., Swartz, W. H., Bucsela, E. J., Joiner, J., Duncan, B. N., Boersma, K. F., Veefkind, J. P., Levelt, P. F., Fioletov, V. E., Dickerson, R. R., He, H., Lu, Z., and Streets, D. G.: Aura OMI observations of regional $\mathrm{SO}_{2}$ and $\mathrm{NO}_{2}$ pollution changes from 2005 to 2015, Atmos. Chem. Phys., 16, 4605-4629, https://doi.org/10.5194/acp-16-4605-2016, 2016.

Lamsal, L. N., Martin, R. V., van Donkelaar, A., Celarier, E. A., Bucsela, E. J., Boersma, K. F., Dirksen, R., Luo, C., and Wang, Y.: Indirect validation of tropospheric nitrogen dioxide retrieved from the OMI satellite instrument: Insight into the seasonal variation of nitrogen oxides at northern midlatitudes, J. Geophys. Res., 115, D05302, https://doi.org/10.1029/2009JD013351, 2010.

Lamsal, L. N., Martin, R. V., Padmanabhan, A., van Donkelaar, A., Zhang, Q., Sioris, C. E., Chance, K., Kurosu, T. P., and Newchurch, M. J.: Application of satellite observations for timely updates to global anthropogenic $\mathrm{NO}_{x}$ emission inventories, Geophys. Res. Lett., 38, L05810, https://doi.org/10.1029/2010GL046476, 2011.

Lei, Y., Zhang, Q., He, K. B., and Streets, D. G.: Primary anthropogenic aerosol emission trends for China, 1990-2005, Atmos. Chem. Phys., 11, 931-954, https://doi.org/10.5194/acp-11-9312011, 2011.

Li, C., McLinden, C., Fioletov, V., Krotkov, N., Carn, S., Joiner, J., Streets, D., He, H., Ren, X., Li, Z., and Dickerson, R. R.: India Is Overtaking China as the World's Largest Emitter of Anthropogenic Sulfur Dioxide, Scientific Reports, 7, 14304, https://doi.org/10.1038/s41598-017-14639-8, 2017.

Li, M., Zhang, Q., Streets, D. G., He, K. B., Cheng, Y. F., Emmons, L. K., Huo, H., Kang, S. C., Lu, Z., Shao, M., Su, H., Yu, X., and Zhang, Y.: Mapping Asian anthropogenic emissions of non-methane volatile organic compounds to multiple 
chemical mechanisms, Atmos. Chem. Phys., 14, 5617-5638, https://doi.org/10.5194/acp-14-5617-2014, 2014.

Li, M., Zhang, Q., Kurokawa, J.-I., Woo, J.-H., He, K., Lu, Z., Ohara, T., Song, Y., Streets, D. G., Carmichael, G. R., Cheng, Y., Hong, C., Huo, H., Jiang, X., Kang, S., Liu, F., Su, H., and Zheng, B.: MIX: a mosaic Asian anthropogenic emission inventory under the international collaboration framework of the MICS-Asia and HTAP, Atmos. Chem. Phys., 17, 935-963, https://doi.org/10.5194/acp-17-935-2017, 2017a.

Li, M., Liu, H., Geng, G., Hong, C., Liu, F., Song, Y., Tong, D., Zheng, B., Cui, H., Man, H., Zhang, Q., and He, K.: Anthropogenic emission inventories in China: a review, Natl. Sci. Rev., 4, 834-866, https://doi.org/10.1093/nsr/nwx150, 2017 b.

Liang, F., Xiao, Q., Wang, Y., Lyapustin, A., Li, G., Gu, D., Pan, X., and Liu, Y.: MAIAC-based long-term spatiotemporal trends of $\mathrm{PM}_{2.5}$ in Beijing, China, Sci. Total Environ., 616-617, 15891598, https://doi.org/10.1016/j.scitotenv.2017.10.155, 2018.

Lin, C. Q., Liu, G., Lau, A. K. H., Li, Y., Li, C. C., Fung, J. C. H., and Lao, X. Q.: High-resolution satellite remote sensing of provincial $\mathrm{PM}_{2.5}$ trends in China from 2001 to 2015, Atmos. Environ., 180, 110-116, https://doi.org/10.1016/j.atmosenv.2018.02.045, 2018.

Lin, J.-T., Liu, M.-Y., Xin, J.-Y., Boersma, K. F., Spurr, R., Martin, R., and Zhang, Q.: Influence of aerosols and surface reflectance on satellite $\mathrm{NO}_{2}$ retrieval: seasonal and spatial characteristics and implications for $\mathrm{NO}_{x}$ emission constraints, Atmos. Chem. Phys., 15, 11217-11241, https://doi.org/10.5194/acp-15-112172015, 2015.

Liu, Z., Guan, D., Wei, W., Davis, S. J., Ciais, P., Bai, J., Peng, S., Zhang, Q., Hubacek, K., Marland, G., Andres, R. J., CrawfordBrown, D., Lin, J., Zhao, H., Hong, C., Boden, T. A., Feng, K., Peters, G. P., Xi, F., Liu, J., Li, Y., Zhao, Y., Zeng, N., and He, K.: Reduced carbon emission estimates from fossil fuel combustion and cement production in China, Nature, 524, 335-338, https://doi.org/10.1038/nature14677, 2015a.

Liu, F., Zhang, Q., Tong, D., Zheng, B., Li, M., Huo, H., and He, K. B.: High-resolution inventory of technologies, activities, and emissions of coal-fired power plants in China from 1990 to 2010, Atmos. Chem. Phys., 15, 13299-13317, https://doi.org/10.5194/acp-15-13299-2015, 2015 b.

Liu, F., Zhang, Q., van der A, R. J., Zheng, B., Tong, D., Yan, L., Zheng, Y. X., and He, K. B.: Recent reduction in $\mathrm{NO}_{x}$ emissions over China: synthesis of satellite observations and emission inventories, Environ. Res. Lett., 11, 114002, https://doi.org/10.1088/1748-9326/11/11/114002, 2016.

Lu, Z., Streets, D. G., Zhang, Q., Wang, S., Carmichael, G. R., Cheng, Y. F., Wei, C., Chin, M., Diehl, T., and Tan, Q.: Sulfur dioxide emissions in China and sulfur trends in East Asia since 2000, Atmos. Chem. Phys., 10, 6311-6331, https://doi.org/10.5194/acp-10-6311-2010, 2010.

Lu, Z., Zhang, Q., and Streets, D. G.: Sulfur dioxide and primary carbonaceous aerosol emissions in China and India, 1996-2010, Atmos. Chem. Phys., 11, 9839-9864, https://doi.org/10.5194/acp-11-9839-2011, 2011.

Miyazaki, K., Eskes, H., Sudo, K., Boersma, K. F., Bowman, K., and Kanaya, Y.: Decadal changes in global surface $\mathrm{NO}_{x}$ emissions from multi-constituent satellite data assimilation, Atmos. Chem. Phys., 17, 807-837, https://doi.org/10.5194/acp-17-8072017, 2017
National Bureau of Statistics: China Energy Statistical Yearbook 2017, China Statistics Press, Beijing, China, 2018a.

National Bureau of Statistics: Statistical Communiqué of the People's Republic of China on the 2017 National Economic and Social Development, http://www.stats.gov.cn/tjsj/zxfb/201802/ t20180228_1585631.html (last access: 30 September 2018), 2018b.

National Bureau of Statistics: China Statistical Yearbook 2017, China Statistics Press, Beijing, China, 2018c.

National Energy Administration: Statistical data of Chinese electric power industry 2017, http://www.nea.gov.cn/2018-01/22/c_ 136914154.htm (last access: 30 September 2018), 2018.

Qi, J., Zheng, B., Li, M., Yu, F., Chen, C., Liu, F., Zhou, X., Yuan, J., Zhang, Q., and He, K.: A high-resolution air pollutants emission inventory in 2013 for the BeijingTianjin-Hebei region, China, Atmos. Environ., 170, 156-168, https://doi.org/10.1016/j.atmosenv.2017.09.039, 2017.

Shao, P., Tian, H., Sun, Y., Liu, H., Wu, B., Liu, S., Liu, X., Wu, Y., Liang, W., Wang, Y., Gao, J., Xue, Y., Bai, X., Liu, W., Lin, S., and $\mathrm{Hu}, \mathrm{G}$. : Characterizing remarkable changes of severe haze events and chemical compositions in multi-size airborne particles $\left(\mathrm{PM}_{1}, \mathrm{PM}_{2.5}\right.$ and $\left.\mathrm{PM}_{10}\right)$ from January 2013 to 20162017 winter in Beijing, China, Atmos. Environ., 189, 133-144, https://doi.org/10.1016/j.atmosenv.2018.06.038, 2018.

Streets, D. G., Zhang, Q., Wang, L., He, K., Hao, J., Wu, Y., Tang, Y., and Carmichael, G. R.: Revisiting China's CO emissions after the Transport and Chemical Evolution over the Pacific (TRACE-P) mission: Synthesis of inventories, atmospheric modeling, and observations, J. Geophys. Res., 111, D14306, https://doi.org/10.1029/2006JD007118, 2006.

Uno, I., He, Y., Ohara, T., Yamaji, K., Kurokawa, J.-I., Katayama, M., Wang, Z., Noguchi, K., Hayashida, S., Richter, A., and Burrows, J. P.: Systematic analysis of interannual and seasonal variations of model-simulated tropospheric $\mathrm{NO}_{2}$ in Asia and comparison with GOME-satellite data, Atmos. Chem. Phys., 7, 16711681, https://doi.org/10.5194/acp-7-1671-2007, 2007.

Valin, L. C., Russell, A. R., Hudman, R. C., and Cohen, R. C.: Effects of model resolution on the interpretation of satellite NO2 observations, Atmos. Chem. Phys., 11, 11647-11655, https://doi.org/10.5194/acp-11-11647-2011, 2011.

van $\operatorname{der}$ A, R. J., Mijling, B., Ding, J., Koukouli, M. E., Liu, F., Li, Q., Mao, H., and Theys, N.: Cleaning up the air: effectiveness of air quality policy for $\mathrm{SO}_{2}$ and $\mathrm{NO}_{x}$ emissions in China, Atmos. Chem. Phys., 17, 1775-1789, https://doi.org/10.5194/acp17-1775-2017, 2017.

Wang, S., Zhang, Q., Martin, R., Philip, S., Liu, F., Li, M., Jiang, X., and He, K.: Satellite measurements oversee China's sulfur dioxide emission reductions from coal-fired power plants, Environ. Res. Lett., 10, 114015, https://doi.org/10.1088/17489326/10/11/114015, 2015.

Warner, J. X., Dickerson, R. R., Wei, Z., Strow, L. L., Wang, Y., and Liang, Q.: Increased atmospheric ammonia over the world's major agricultural areas detected from space, Geophys. Res. Lett., 44, 2875-2884, https://doi.org/10.1002/2016GL072305, 2017.

World Health Organization: WHO Air quality guidelines for particulate matter, ozone, nitrogen dioxide and sulfur dioxide, available at: http://apps.who.int/iris/bitstream/handle/10665/ 69477/WHO_SDE_PHE_OEH_06.02_eng.pdf;jsessionid= 
2316300A203942FCECC2E260E5EB9A14?sequence $=1$ (last access: 30 September 2018), 2006.

Zhang, J., Reid, J. S., Alfaro-Contreras, R., and Xian, P.: Has China been exporting less particulate air pollution over the past decade?, Geophys. Res. Lett., 44, 2941-2948, https://doi.org/10.1002/2017GL072617, 2017.

Zhang, Q., Streets, D. G., He, K., Wang, Y., Richter, A., Burrows, J. P., Uno, I., Jang, C. J., Chen, D., Yao, Z., and Lei, Y.: $\mathrm{NO}_{x}$ emission trends for China, 1995-2004: The view from the ground and the view from space, J. Geophys. Res., 112, D22306, https://doi.org/10.1029/2007JD008684, 2007.

Zhang, Q., Streets, D. G., Carmichael, G. R., He, K. B., Huo, H., Kannari, A., Klimont, Z., Park, I. S., Reddy, S., Fu, J. S., Chen, D., Duan, L., Lei, Y., Wang, L. T., and Yao, Z. L.: Asian emissions in 2006 for the NASA INTEX-B mission, Atmos. Chem. Phys., 9, 5131-5153, https://doi.org/10.5194/acp-9-5131-2009, 2009.

Zhang, Q., He, K., and Huo, H.: Cleaning China's air, Nature, 484, 161-162, https://doi.org/10.1038/484161a, 2012.

Zhao, B., Jiang, J. H., Gu, Y., Diner, D., Worden, J., Liou, K. N., Su, H., Xing, J., Garay, M., and Huang, L.: Decadalscale trends in regional aerosol particle properties and their linkage to emission changes, Environ. Res. Lett., 12, 054021, https://doi.org/10.1088/1748-9326/aa6cb2, 2017.
Zhao, Y., Nielsen, C. P., Lei, Y., McElroy, M. B., and Hao, J.: Quantifying the uncertainties of a bottom-up emission inventory of anthropogenic atmospheric pollutants in China, Atmos. Chem. Phys., 11, 2295-2308, https://doi.org/10.5194/acp-112295-2011, 2011.

Zheng, B., Huo, H., Zhang, Q., Yao, Z. L., Wang, X. T., Yang, X. F., Liu, H., and He, K. B.: High-resolution mapping of vehicle emissions in China in 2008, Atmos. Chem. Phys., 14, 9787-9805, https://doi.org/10.5194/acp-14-9787-2014, 2014.

Zheng, B., Zhang, Q., Tong, D., Chen, C., Hong, C., Li, M., Geng, G., Lei, Y., Huo, H., and He, K.: Resolution dependence of uncertainties in gridded emission inventories: a case study in Hebei, China, Atmos. Chem. Phys., 17, 921-933, https://doi.org/10.5194/acp-17-921-2017, 2017.

Zheng, B., Chevallier, F., Ciais, P., Yin, Y., Deeter, M., Worden, H., Wang, Y. L., Zhang, Q., and He, K. B.: Rapid decline in carbon monoxide emissions and export from East Asia between years 2005 and 2016, Environ. Res. Lett., 13, 044007, https://doi.org/10.1088/1748-9326/aab2b3, 2018. 